Experimental and numerical study of chemiluminescent species in low-pressure flames

Trupti Kathrotia $^{1}$, Uwe Riedel ${ }^{1}$, Angela Seipel $^{2}$, Kai Moshammer $^{2}$, Andreas Brockhinke ${ }^{2}$

${ }^{1}$ University of Stuttgart and Institute of Combustion Technology, German Aerospace Center (DLR),

Pfaffenwaldring 38-40, 70569 Stuttgart

${ }^{2}$ Universität Bielefeld, Physikalische Chemie 1, Universitätsstraße 25, 33615 Bielefeld

Appl Phys B (2012), Volume 107, page 571-584

The original publication is available at www.springerlink.com

http://dx.doi.org/10.1007/s00340-012-5002-0 


\title{
Experimental and numerical study of chemiluminescent species in low-pressure \\ flames
}

\author{
Trupti Kathrotia ${ }^{1}$, Uwe Riedel ${ }^{1}$, Angela Seipel ${ }^{2}$, Kai \\ Moshammer $^{2}$, Andreas Brockhinke ${ }^{2}$ \\ 1 University of Stuttgart and Institute of Combustion Technology, German Aerospace \\ Center (DLR), Pfaffenwaldring 38-40, 70569 Stuttgart \\ 2 Universität Bielefeld, Physikalische Chemie 1, Universitätsstraße 25, 33615 Biele- \\ feld
}

Received: date / Revised version: date

\begin{abstract}
Chemiluminescence has been observed since the beginning of spectroscopy, nevertheless, important facts still remain unknown. Especially, reaction pathways leading to chemiluminescent species such as $\mathrm{OH}^{*}, \mathrm{CH}^{*}$, $\mathrm{C}_{2}{ }^{*}$, and $\mathrm{CO}_{2}{ }^{*}$ are still under debate and cannot be modeled with standard codes for flame simulation. In several cases, even the source species of spectral features observed in flames are unknown. In recent years, there has been renewed interest in chemiluminescence, since it has been shown that this radiation can be used to determine flame parameters such as stoichiometry and heat release under some conditions.

In this work, we present a reaction mechanism which predicts the $\mathrm{OH}^{*}$, $\mathrm{CH}^{*}$ (in $\mathrm{A}$ - and B-state), and $\mathrm{C}_{2}{ }^{*}$ emission strength in lean to fuel-rich stoichiometries. Measurements have been performed in a set of low-pressure flames which have already been well characterized by other methods. The flame front is resolved in these measurements, which allows a comparison of shape and position of the observed chemiluminescence with the respective simulated concentrations. To study the effects of varying fuels, methane flame diluted in hydrogen are measured as well. The 14 investigated premixed methane-oxygen-argon and methane-hydrogen-oxygen-argon flames span a wide parameter field of fuel stoichiometry $(\phi=0.5$ to 1.6$)$ and hydrogen content $\left(\mathrm{H}_{2}\right.$ vol\% $=0$ to 50$)$.

The relative comparison of measured and simulated excited species concentrations shows good agreement. The detailed and reliable modeling for several chemiluminescent species permits correlating heat release with all of these emissions under a large set of flame conditions. It appears from
\end{abstract}

Correspondence to: Trupti Kathrotia, trupti.kathrotia@dlr.de 
the present study that the normally used product of formaldehyde and $\mathrm{OH}$ concentration may be less well suited for such a prediction in the flames under investigation.

\section{Introduction}

Under many practical operating conditions, i.e. at very lean mixtures or low temperatures, modern combustors are subject to instabilities due to heat release fluctuations. Sensors for the active control of such unstable conditions should be fast, robust and non-intrusive in nature [6]. Chemiluminescence of flames may provide a well-suited inherent monitor of the combustion process $[2,12,17,24]$, since the emission of excited species from flames is intricately coupled to the flame chemistry. Chemiluminescence intensities and intensity ratios involving mostly $\mathrm{OH}^{*}, \mathrm{CH}^{*}$, and $\mathrm{C}_{2}{ }^{*}$ emissions have been analyzed and correlated to combustion properties such as stoichiometry or heat release, which allows their application in control. Moreover, chemiluminescence provides cost benefits over conventional laser techniques. A reaction mechanism that can accurately predict such species will be extremely valuable to assess these correlations.

Studies of excited species are not new and have been done since Gaydon in 1974 [11]. However, the detailed reaction kinetics and sometimes even the major formation pathways of these species in flames still remain under debate. This is due to the fact that their reactions constitute only a minor part of the overall combustion process and are usually only indirectly linked to the major reaction branches. Therefore, experimental determination of rate coefficients for reactions forming these species is usually quite difficult.

All luminescence occurring due to chemical excitation is called chemiluminescence. In hydrocarbon flames, the four major emitters found are $\mathrm{OH}^{*}, \mathrm{CH}^{*}, \mathrm{C}_{2}{ }^{*}$, and $\mathrm{CO}_{2}{ }^{*}[11]$, here star $\left(^{*}\right)$ refers to electronically excited molecules. Flame spectra in the visible and ultra-violet (UV) region are dominated by these emissions, an overview spectrum is shown in Fig. 1. The $\mathrm{OH}^{*}$ chemiluminescence with a peak intensity at about $309 \mathrm{~nm}$ originates from the doublet $\Sigma$ state $\mathrm{OH}\left(\mathrm{A}^{2} \Sigma^{+}\right)$. Emissions from the other excited states $\mathrm{OH}\left(\mathrm{B}^{2} \Sigma^{+}\right)$and $\mathrm{OH}\left(\mathrm{C}^{2} \Sigma^{+}\right)$are weak and could not be identified in any of the flames investigated here. In the $\mathrm{CH}^{*}$ spectrum, three major bands are emitted by the $\mathrm{CH}$ molecule. The one seen at a wavelength of $431 \mathrm{~nm}$ originates from $\mathrm{CH}\left(\mathrm{A}^{2} \Delta\right)$ and is the strongest of the three bands (it accounts for about $80 \%$ of the total $\mathrm{CH}^{*}$ emissions) and appears blue in the visible region. Around $390 \mathrm{~nm}$, the much weaker emissions originating from $\mathrm{CH}\left(\mathrm{B}^{2} \Sigma^{-}\right)$can be seen. Emission originating from $\mathrm{CH}\left(\mathrm{C}^{2} \Delta\right)$ is even weaker and is obscured by the strong $\mathrm{OH}^{*}$ emissions in this region. In the present work, we consider only $\mathrm{CH}\left(\mathrm{A}^{2} \Delta\right)$ and $\mathrm{CH}\left(\mathrm{B}^{2} \Sigma^{-}\right)$states (referred as $\mathrm{CH}(\mathrm{A})$ and $\mathrm{CH}(\mathrm{B})$, respectively). Chemiluminescence of the Swan bands $\mathrm{C}_{2}(\mathrm{~d}-\mathrm{a})$ (hereafter referred as $\mathrm{C}_{2}{ }^{*}$ ) is observed in the visible region of flame spectra between $436 \mathrm{~nm}$ and $564 \mathrm{~nm}$, mainly in fuel-rich gas mixtures. 


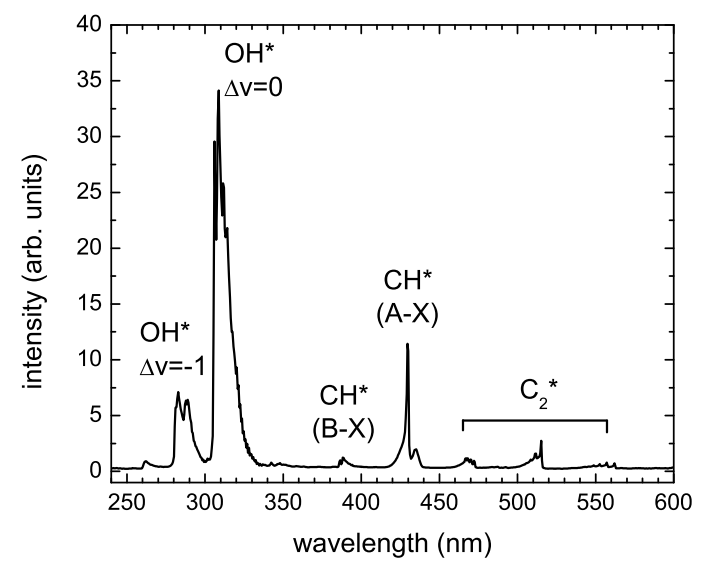

Fig. 1 Chemiluminescence spectrum of a $\mathrm{CH}_{4} / \mathrm{O}_{2}$ flame with $30 \% \mathrm{H}_{2}$ addition.

Only few papers have been published where both subjects, measurement and modeling of chemiluminescence are addressed. Recent studies include flame measurement and modeling of Smith et al. [38-40] and shock-tube studies of Hall et al. [14,15]. Smith et al. presented a quantitative measurement of $\mathrm{OH}^{*}, \mathrm{CH}^{*}$, and $\mathrm{C}_{2}{ }^{*}$ chemiluminescence in low pressure methane-air flames. A comparison of experimentally measured concentrations with simulations using GRI-mech 3.0 [37] (with added excited species) shows a good prediction of these species. Based on these results, reaction rates of $\mathrm{OH}^{*}$, $\mathrm{CH}^{*}$, and $\mathrm{C}_{2}{ }^{*}$ formation reactions have been recommended. Also, Hall et al. [15] in their shock-tube studies suggested the major reactions of $\mathrm{OH}^{*}$ formation and recommended their rate coefficient obtained by a fitting approach. Recently, in [20] we recommended a three-body reaction rate of $\mathrm{OH}^{*}$ formation in hydrogen oxidation. Very recently, Bozkurt et al. [3] in their shock-tube study, suggested $\mathrm{OH}^{*}$ and $\mathrm{CH}^{*}$ formation rates in $\mathrm{H}_{2} / \mathrm{CH}_{4}$ and $\mathrm{C}_{2} \mathrm{H}_{2}$ mixtures diluted in $\mathrm{O}_{2}$ and $\mathrm{N}_{2} \mathrm{O}$.

In this study, we present measurements in a set of flames that has already been well-characterized by other experimental and numerical methods $[22,41,42]$. The flames are flat and therefore reaction progress is welldescribed by only one spatial coordinate. Additionally, experiments have been conducted at low pressure, which broadens the reaction zone. This facilitates comparison of the shape of measured chemiluminescence profiles with model results. Spatially resolved profiles of all major chemiluminescent species $\left(\mathrm{OH}^{*}, \mathrm{CH}^{*}, \mathrm{C}_{2}{ }^{*}\right)$ have been recorded for a total of $14 \mathrm{CH}_{4} / \mathrm{O}_{2}$ flames with different stoichiometries and hydrogen dilution. Additionally, we present the first detailed study distinguishing between chemiluminescence originating from the $\mathrm{CH}$ A- and B-state. 


\section{Chemiluminescent reaction kinetics}

The chemiluminescence reaction kinetics requires the knowledge of the important reactions for the formation and consumption of excited species and their reaction rates. The identification of the formation pathways of excited species from active intermediates and their consumption by radiative decay or collisional quenching pathways is usually the subject of separate studies. The rate of consumption can be obtained from the lifetime of the chemiluminescent species and is mostly better known [43] in comparison to the formation rates. The first measurement and detailed kinetics studies were done in the 1970s by Gaydon [11]. Since then, significant progress has been made in this field. However, the fundamental understanding on the relation between the measured intensity and the simulated concentrations of the chemiluminescent species is still lacking. Therefore, uncertainty still exists about the important formation reactions specifically for $\mathrm{CH}^{*}$ and $\mathrm{C}_{2} *$ formation. The concentration of these excited species is typically more than five orders of magnitude lower than those to the corresponding ground state species. Therefore, their presence has little impact on the overall oxidation process. Due to their low production and rapid removal rates, they are often assumed to be in quasi-steady state [31].

\section{1 $C_{1}-C_{4}$ Hydrocarbon oxidation}

The underlying $\mathrm{C}_{1}$ to $\mathrm{C}_{4}$ hydrocarbon mechanism is recently documented in the dissertation of T. Kathrotia [20]. A complete description of the oxidation of hydrocarbons in the low and high temperature range requires incorporation of $\mathrm{RO}_{2}, \mathrm{RO}_{2} \mathrm{H}$, aldehyde species, and radicals along with single, double and triple bond RH. This mechanism has been developed to model basic fuels under non-sooting conditions. It has recently been modified for important intermediates such as $\mathrm{CH}, \mathrm{C}_{2} \mathrm{H}, \mathrm{C}_{2}$, which are important for prediction of chemiluminescent species [20].

Acetylene plays an important role under fuel-rich conditions and is an important precursor for the formation and growth of soot. In the context of chemiluminescence, the acetylene chemistry is important as it has a major impact on the formation of intermediate species such as $\mathrm{C}_{2} \mathrm{H},{ }^{1} \mathrm{CH}_{2}, \mathrm{CH}$, and $\mathrm{C}_{2}$ which in turn are responsible for the production of $\mathrm{OH}^{*}, \mathrm{CH}^{*}$, and $\mathrm{C}_{2}{ }^{*}$. Due to the low concentration of the excited species, any uncertainty in the prediction of their precursors directly translates into the quality of their own prediction [38]. Therefore, a good prediction of these precursor species is extremely important. The validation of $\mathrm{CH},{ }^{1} \mathrm{CH}_{2}, \mathrm{C}_{2}$, and $\mathrm{C}_{2} \mathrm{H}_{2}$ in the mechanism is discussed later and in [20].

\subsection{Chemiluminescence mechanism}

The main proposed reaction responsible for $\mathrm{OH}^{*}$ formation in hydrogen and in hydrocarbon mixtures is $\mathrm{H}+\mathrm{O}+\mathrm{M} \rightarrow \mathrm{M}+\mathrm{OH}^{*}(\mathrm{R} 1)$ and $\mathrm{CH}+\mathrm{O}_{2}$ 
$\rightarrow \mathrm{CO}+\mathrm{OH}^{*}(\mathrm{R} 2)$, respectively $[15,38]$. The three-body recombination reaction $(\mathrm{R} 1)$ is important at temperatures below $2800 \mathrm{~K}$ where chemical excitation dominates thermal excitation [19]. Smith et al. [39] suggested $\mathrm{H}+2 \mathrm{OH} \rightarrow \mathrm{H}_{2} \mathrm{O}+\mathrm{OH}^{*}$, in addition to (R1), in their hydrogen flame study. However, its contribution is negligible in most methane flames. The reaction of $\mathrm{CH}$ with molecular oxygen (R2) has been initially proposed by Krishnamachari and Broida [25] who studied the emission spectra of oxygenacetylene flames at low pressures. The lesser known reaction of $\mathrm{HCO}+\mathrm{O}$ is suggested by Haber and Vandsburger [13].

Three major reactions are proposed in the literature for the formation of $\mathrm{CH}^{*}$. Gaydon [11] suggested the origin of the $\mathrm{CH}^{*}$ emission in hydrocarbon flames to be due to the reaction of dicarbon with a hydroxyl radical $\left(\mathrm{C}_{2}+\mathrm{OH} \rightarrow \mathrm{CO}_{2}+\mathrm{CH}^{*}\right)$. Hand and Kistiakowsky (1962) [16] studied acetylene-oxygen reactions in shock waves and proposed the reactions of $\mathrm{C}_{2} \mathrm{H}$ with molecular and atomic oxygen $\left(\mathrm{CH}_{2}+\mathrm{O}_{2}\right.$ (or $\left.\mathrm{O}\right) \rightarrow \mathrm{CO}_{2}$ (or $\mathrm{CO}$ ) $\left.+\mathrm{CH}^{*}\right)$. Among the $\mathrm{CH}^{*}$ excited states, the major emission of about $80 \%$ of total $\mathrm{CH}^{*}$, stems from the $\mathrm{CH}(\mathrm{A}-\mathrm{X})$ transition whereas only $20 \%$ are from the other two transitions, mainly from $\mathrm{CH}(\mathrm{B}-\mathrm{X})$ [38]. Up to now, only the $\mathrm{CH}(\mathrm{A})$ state (frequently named as 'total $\mathrm{CH}^{*}$ ') has been modeled in the literature. In this study, we modeled both, $\mathrm{CH}(\mathrm{A})$ and $\mathrm{CH}(\mathrm{B})$, for the first time.

The chemiluminescence from the $\mathrm{C}_{2}(\mathrm{~d}-\mathrm{a})$ Swan band is mainly found between $470-550 \mathrm{~nm}$ in flame spectra (cf. Fig. 1). The reactions proposed for its formation are the reactions of $\mathrm{CH}_{2}+\mathrm{C} \rightarrow \mathrm{H}_{2}+\mathrm{C}_{2} *$ and $\mathrm{C}_{3}+\mathrm{O} \rightarrow$ $\mathrm{CO}+\mathrm{C}_{2}{ }^{*}$, first identified by Gaydon [11] and Savadatti and Broida [35], respectively.

As a starting point of the modeling approach, literature values have been used for the rates of formation. The mechanism incorporating these reactions rates was then tested against the only available quantitative measurements of Smith et al. [38] in low-pressure $\mathrm{CH}_{4}$-air flames. Necessary modifications to the reactions rates were done in order to achieve best fit to the measurements at all three fuel stoichiometries $(\phi=0.8,1.08,1.28)$ as discussed in [20]. The rates of these reactions are further discussed in Section 5 and are summarized in Table 5.

The radiative decay and quenching reaction rates of $\mathrm{OH}^{*}$ and $\mathrm{CH}(\mathrm{A})$, for most quenchers except Ar, are recommended in Tamura et al. [43] at flame temperatures. Smith et al. [40] provided overall quenching rate of $\mathrm{C}_{2}{ }^{*}$. These rates were integrated into our reaction mechanism. The quenching rates of $\mathrm{CH}(\mathrm{B})$ state are less extensively studied compared to other excited species. Rensberger et al. [33] predicted the total (all colliding species) quenching rate of $\mathrm{CH}(\mathrm{B})$ at a flame temperature of $1800 \mathrm{~K}$. In the present work, the room temperature quenching rates for various colliding partners from Cooper et al. [8] and Chen et al. [7] have been added to the mechanism. 


\section{Experimental}

Laminar, premixed, flat $\mathrm{CH}_{4}-\mathrm{O}_{2}-\mathrm{Ar}$ and $\mathrm{CH}_{4}-\mathrm{H}_{2}-\mathrm{O}_{2}-\mathrm{Ar}$ flames at 0.05 bar are studied in a setup, that has already been well-characterized before with several optical and mass-spectrometric techniques as well as numerical models $[22,41,42]$. One advantage of these flames is that the shape of flame front can be resolved (which usually is not possible with CL-measurements in atmospheric-pressure flames) [24]. Flames are stabilized on a home-made sintered bronze matrix burner with $63 \mathrm{~mm}$ diameter which is kept at $40^{\circ} \mathrm{C}$ by means of thermostated water circulation. The burner is moved vertically for height-resolved scans. Gas flows are regulated by mass flow controllers (Mykrolis Tylan FC/DFC 2900/2910), calibrated flows are in slm (standard liters per minute at 1.013 bar and $0^{\circ} \mathrm{C}$ ). All flames are diluted with a $1.1 \mathrm{slm}$ argon flow.

The $\mathrm{CH}_{4}-\mathrm{O}_{2}$ flames are measured at different fuel stoichiometries (see Table 1). The six lean to rich $(\phi=0.5,1.0,1.2,1.4,1.5$, and 1.6) methane flames are measured at a low pressure of 0.05 bar. In addition to this, these flames are diluted with additional $\mathrm{H}_{2}$ to see its effect on chemiluminescence. The inlet flowrates of these $\mathrm{CH}_{4}-\mathrm{H}_{2}-\mathrm{O}_{2}$ - Ar flames are summarized in Table 1. The $\mathrm{CH}_{4}-\mathrm{H}_{2}-\mathrm{O}_{2}$-Ar flames are measured for stoichiometric $(\phi=1.0)$ and fuel-rich $(\phi=1.5)$ mixtures with a $\mathrm{H}_{2}$ dilution ranging from 10 to $50 \%$. The flame temperatures shown in Fig. 2 have been measured via NO-LIF with an uncertainty of about $\Delta T= \pm 100 \mathrm{~K}$.

Table 1 Experimental condition of $\mathrm{CH}_{4}-\mathrm{O}_{2}-\mathrm{Ar}$ and $\mathrm{CH}_{4}-\mathrm{H}_{2}-\mathrm{O}_{2}$-Ar flame measured at 0.05 bar on a McKenna burner. The measured flowrate is given in Standard Liters per Minute (slm). All flames have been diluted with a $1.1 \mathrm{slm}$ argon flow.

\begin{tabular}{ccccc}
\hline$\phi$ & $\mathrm{H}_{2}(\%)$ & $\mathrm{CH}_{4}(\mathrm{slm})$ & $\mathrm{H}_{2}(\operatorname{slm})$ & $\mathrm{O}_{2}(\mathrm{slm})$ \\
\hline & 10 & 1.04 & 0.12 & 2.15 \\
1.0 & 20 & 0.98 & 0.25 & 2.08 \\
& 30 & 0.91 & 0.39 & 2.01 \\
& 50 & 0.74 & 0.74 & 1.84 \\
\hline & 10 & 1.33 & 0.15 & 1.83 \\
1.5 & 20 & 1.24 & 0.31 & 1.76 \\
& 30 & 1.14 & 0.49 & 1.68 \\
& 50 & 0.90 & 0.90 & 1.50 \\
\hline 0.5 & - & 0.66 & - & 2.65 \\
1.0 & - & 1.10 & - & 2.21 \\
1.2 & - & 1.24 & - & 2.07 \\
1.4 & - & 1.36 & - & 1.95 \\
1.5 & - & 1.42 & - & 1.89 \\
1.6 & - & 1.47 & - & 1.84 \\
\hline \hline
\end{tabular}




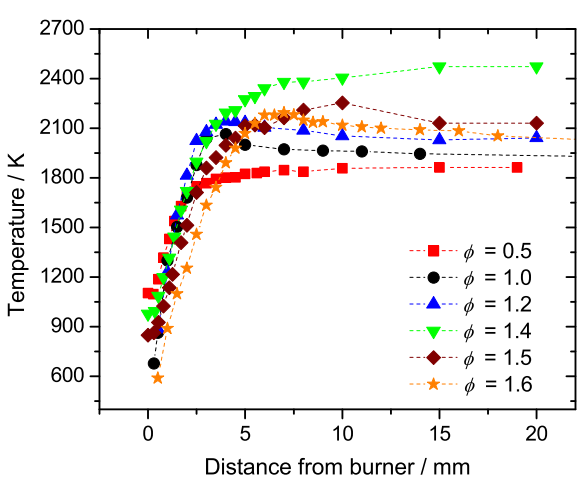

Fig. 2 Temperature profiles (measured with NO-LIF) for $\mathrm{CH}_{4}-\mathrm{O}_{2}-\mathrm{Ar}$ flames at different fuel stoichiometries.

Chemiluminescence spectra in low- and atmospheric-pressure flames are resolved using a $300 \mathrm{~mm}$ focal length monochromator (Acton SpectraPro 2300i). The emitted radiation is collected with an $125 \mathrm{~mm}$ diameter mirror (collimated down to $50 \mathrm{~mm}$ equaling $\mathrm{F} / 9$ for the complete optics) to avoid chromatic aberrations. Detection is performed with an unintensified camera (Roper Scientific Pixis 256). Three gratings (150, 600, and 2400 grooves $/ \mathrm{mm}$ ) are used to measure overview, moderate-, and high-resolution spectra. The setup permits to record spectra in the entire range from 200$1100 \mathrm{~nm}$, which is typically covered in two portions from $200-700 \mathrm{~nm}$, and 600-1100 nm. Integration times are chosen, depending on application, between $100 \mathrm{~ms}$ for luminous flames up to $20 \mathrm{~s}$ for high-resolution spectra.

The advantage of using a low-pressure burner for comparison between model and experiment is that these flames can be modeled with a high degree of reliability, that heat loss to the burner surface is low, and, especially, that the reduced pressure leads to a broadening of the reaction zone to a thickness of several $\mathrm{mm}$. This means that not only the relative position of the luminescence but also the shape of the obtained profiles can be compared with the model. On the downside, this setup leads to additional challenges for the experimenter: reflections inside of the burner housing, shading through the burner head and the effect of the large diameter of the reaction zone (which leads to a broadening of the measured profiles especially when low F-number optics are used) has to be controlled. A careful calibration of the optical setup was conducted using a luminous plastic sheet as reference (thickness $400 \mu \mathrm{m}$, same diameter as the burner). This plastic sheet emits visible radiation upon irradiation with UV radiation and thus perfectly mimics the emission zone. By moving it along the centerline and at different distances to the burner surface, all of the aforementioned effects could be taken into account.

Since the emission of the chemiluminescent species investigated in this study is well separated in the wavelength-resolved spectra (see Fig. 1), their intensity could be integrated over the complete band for each of the species. 
In order to be able to compare the relative concentration of the chemiluminescent species, the different emissivities have to be corrected. For this, the LifBAse database [26] has been used. For $\mathrm{OH}^{*}, \mathrm{CH}(\mathrm{A})$ and $\mathrm{CH}(\mathrm{B})$, averaged Einstein-coefficients of $5.0132 \times 10^{5}, 5.70465 \times 10^{5}$, and $1.2 \times 10^{6} \mathrm{~s}^{-1}$ have been used, respectively. $\mathrm{C}_{2} *$ cannot be simulated with LIFBASE and information about emission strengths is sparse. In this work, we used a value of $5.5 \times 10^{6} \mathrm{~s}^{-1}$.

Initially, we did not attempt to quantify the absolute concentration of the chemiluminescent species in this experiment, but concentrated on reliable profiles of the relative intensities. However, due to recent availability of the quantitative information for two stoichiometries $(\phi=1.0$ and 1.6) in [48], the excited species intensities are quantified to the absolute values by using a conversion factor from this reference.

\section{Modeling}

The reaction mechanism includes reactions of hydrocarbon oxidation and reactions describing formation and consumption of excited species. It includes a total of 69 species and 946 forward and backward reactions. Black body radiation, which is a clear indicator for soot formation, was never observed in the low-pressure flames investigated here. Therefore, it was not necessary to include soot formation reactions to the mechanism. The simulations of one-dimensional laminar premixed flame are performed with the flame code INSFLA $[27,28]$. Initial mixture composition, gas flow rate, pressure at burner surface and measured spatial temperature profile are used as input to the simulations. The thermodynamic data are from the Goos-Burcat database [5]. The kinetic analysis of reaction mechanism is performed with postprocessor KINALC [44]. In addition, simulations at several experimental conditions were also performed with GRI-mech 3.0 citeSmith1999 with added chemiluminescence and $\mathrm{C}_{2}$ reactions set extracted from [38-40] (referred to as GRI3.0+CL in the present work).

\section{Results and discussion}

Output of each simulation of a one-dimensional flame are computed mole fraction profiles versus the height above the burner surface. The reaction rates of the chemiluminescence reactions have been varied and their implication on the resulting concentrations were investigated. The reaction mechanism resulting from the analysis is summarized in Table 5. In addition, the comparative study with GRI3.0+CL allows to assess the predictive capability of both mechanisms. 


\subsection{Methane flames}

5.1.1 $\mathrm{OH}^{*}$ The $\mathrm{OH}^{*}$ formation pathways are better known than those of the other chemiluminescent species. The formation and consumption of $\mathrm{OH}^{*}$ are sensitive to the precursors prediction. For the $\mathrm{OH}^{*}$ formation, the major precursor is the $\mathrm{CH}$ radical $\left(\mathrm{CH}+\mathrm{O}_{2}(\mathrm{R} 2)\right)$. Therefore, we compared the prediction of $\mathrm{CH}$ at similar conditions. The $\mathrm{CH}$ concentrations in $\mathrm{CH}_{4}-\mathrm{O}_{2}-$ Ar flames have been measured by Thoman et al. [47] and are shown in Fig. 3. We compared the prediction of our mechanism and GRI-mech 3.0 [37] with the measurements.

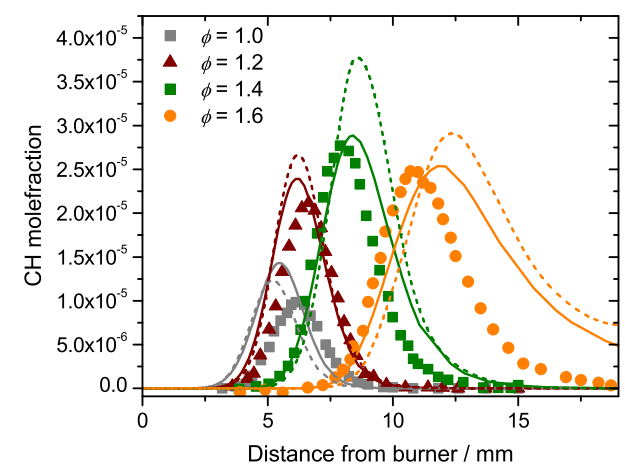

Fig. 3 Measured and simulated absolute $\mathrm{CH}$ concentrations for $\mathrm{CH}_{4}-\mathrm{O}_{2}-\mathrm{Ar}$ flames at four fuel stoichiometries $(\phi=1.0,1.2,1.4$, and 1.6). Experiments: Thoman et al. [47]. Symbols: experiments, line: simulation present work, dashed line: simulation with GRI-mech 3.0 [37].

Overall, the $\mathrm{CH}$ concentrations are well predicted by both mechanisms as seen in Fig. 3. The GRI-mech 3.0 tends to overpredict $\mathrm{CH}$ mole fractions by factor of about 1.3. Our mechanism performs even better, except for $\phi=1.0(\mathrm{CH}$ overpredicted by factor of 1.4$)$. At very rich condition $(\phi=$ 1.6), the decay of the modeled profile from both mechanisms is slower than the experimental slope. This may be due to the consumption of $\mathrm{CH}$ in the formation of higher hydrocarbon species.

In the present work, we considered the three-body reaction rate $k_{(\mathrm{R} 1)}=$ $1.25 \times 10^{13} \mathrm{~cm}^{6} \mathrm{~mol}^{-2} \mathrm{~s}^{-1} \exp \left(-25 R^{-1} T^{-1} \mathrm{kJmol}^{-1}\right)$ from [19] and $k_{(\mathrm{R} 2)}=$ $1.8 \times 10^{11} \mathrm{~cm}^{3} \mathrm{~mol}^{-1} \mathrm{~s}^{-1}$ recommended by Smith et al. [38]. Figure 4 shows a comparison of the measured and simulated $\mathrm{OH}^{*}$ profiles for different stoichiometries. The maximum $\mathrm{OH}^{*}$ mole fractions increase from lean to stoichiometric fuel conditions and start decreasing as mixtures becomes more fuel-rich. The shape of the profiles and their peak position are in good agreement with the measurements. In fuel-rich flames, the $\mathrm{OH}^{*}$ peak value decreases. This is due to the fact that $\mathrm{OH}^{*}$ in methane mixtures is mainly formed by reactions of ground state $\mathrm{CH}$ with $\mathrm{O}_{2}$. In rich flames, $\mathrm{CH}$ is consumed by reactions forming higher hydrocarbons. 


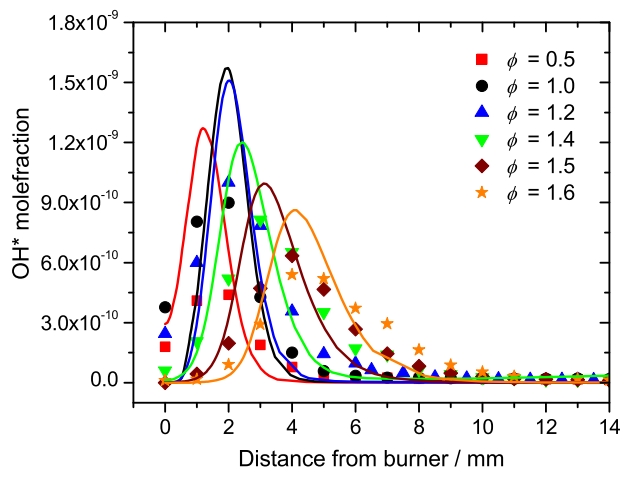

Fig. 4 Comparison of measured and calculated $\mathrm{OH}^{*}$ mole fraction profiles at different fuel stoichiometries. The premixed $\mathrm{CH}_{4}-\mathrm{O}_{2}$-Ar flame conditions are as presented in Table 1. Symbols: experiment, line: simulation with mechanism from present work.

Similarly, Fig. 5 shows the same comparison of $\mathrm{OH}^{*}$ with the GRI3.0+CL mechanism at different fuel stoichiometries. A maximum deviation between the two mechanisms is seen for $\phi=0.5$. Here, our mechanism overpredicts the $\mathrm{OH}^{*}$ peak value by factor of three while it is two times underpredicted by the GRI3.0+CL mechanism. The difference in both values is the result of the ground state $\mathrm{CH}$ concentrations. At $\phi=1.0$, our $\mathrm{OH}^{*}$ prediction are higher than predicted by GRI3.0+CL, which is consistent with the ground state $\mathrm{CH}$ predictions seen in Fig. 3. At richer mixtures, the peak positions of both mechanisms are similar and agree with the $\mathrm{OH}^{*}$ measurements.

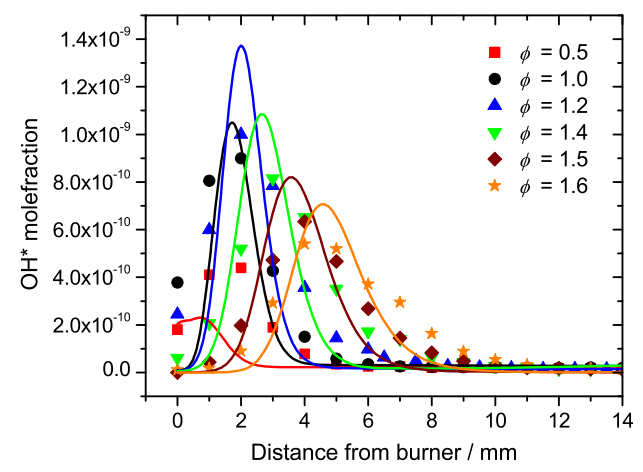

Fig. 5 Comparison of measured $\mathrm{OH}^{*}$ and $\mathrm{OH}^{*}$ mole fraction simulated with GRI3.0+CL at different fuel stoichiometries. The premixed $\mathrm{CH}_{4}-\mathrm{O}_{2}-\mathrm{Ar}$ flame conditions are as presented in Table 1. Symbols: experiment, line: simulation.

At some stoichiometries $(\phi=1.4,1.5)$, both mechanisms show faster decaying $\mathrm{OH}^{*}$ profiles than visible in the experiments. However, this trend 
is not uniform and is, e.g., not seen at $\phi=1.6$. The major difference between two mechanisms with respect to $\mathrm{OH}^{*}$ chemistry is the rate of reaction (R1) and additional three body reaction $\left(\mathrm{H}+2 \mathrm{OH} \rightarrow \mathrm{H}_{2} \mathrm{O}+\right.$ $\left.\mathrm{OH}^{*}\right)$ in GRI3.0+CL, both of which plays minor role in hydrocarbon combustion. Also the quenching of $\mathrm{OH}^{*}$ with $\mathrm{H}$ and $\mathrm{OH}$ is not included in GRI3.0+CL. However, its effect remains negligible as these two species are minor quenchers. If we added the three body reaction $\mathrm{H}+2 \mathrm{OH}$ to our mechanism, the results in Fig. 4 were 10\% lower than in its peak value, thereby the results at rich conditions were comparable with results from GRI3.0+CL. The three body reaction act as a consumption channel of $\mathrm{OH}^{*}$ at condition of given work and consumes about $10 \%$ of $\mathrm{OH}^{*}$ thereby lowering the $\mathrm{OH}^{*}$ concentration. Considering the suggested $40 \%$ and $49 \%$ uncertainty limits in the $k_{(\mathrm{R} 1)}$ and $k_{(\mathrm{R} 2)}$, respectively, the measured $\mathrm{OH}^{*}$ profiles are well reproduced by the simulations.

The $k_{(\mathrm{R} 2)}$ recommended by Bozkurt et al. [3] is about 2.2 times lower than the prediction of Smith et al. [38]. However, considering the upper limit of their derived $32 \%$ uncertainty, the resulting rate is similar to [38] and the $\mathrm{OH}^{*}$ profiles would result in agreement with the measurements. Based on their shock tube studies, Hall et al. [15] recommended relatively high rates for (R1) and (R2). With these reaction rates in both mechanisms, the $\mathrm{OH}^{*}$ prediction is about 35-40 times higher than the measurements. Therefore, we assume that the rates derived at high pressure (0.6-2.2 bar) and high temperature (1200-2300 K) are not suitable for the low pressure flames investigated here. At our flame conditions, the reaction rates of $k_{(\mathrm{R} 1)}$ and $k_{(\mathrm{R} 2)}$ recommended by Smith et al. [38,39] reproduces the measured $\mathrm{OH}^{*}$ profiles quite well.

5.1.2 $\mathrm{CH}(\mathrm{A})$ The prediction of $\mathrm{CH}(\mathrm{A})$ is more challenging compared to $\mathrm{OH}^{*}$ and $\mathrm{C}_{2}{ }^{*}$ since it involves intermediates species whose validation is difficult. All the reactions proposed as the origin of $\mathrm{CH}^{*}$ chemiluminescence are included in the mechanism. Smith et al. [38-40] presented first quantitative measurements of $\mathrm{CH}(\mathrm{A})$ at three fuel stoichiometries. Based on the comparison between measured and simulated number densities, they recommended the rates of reactions $\mathrm{C}_{2} \mathrm{H}+\mathrm{O}_{2}$ (R13) and $\mathrm{C}_{2} \mathrm{H}+\mathrm{O}$ (R14) forming $\mathrm{CH}(\mathrm{A})$. Also, the reactions of $\mathrm{C}_{2}+\mathrm{OH}(\mathrm{R} 15)$ and $\mathrm{C}+\mathrm{H}+\mathrm{M}$ (R16) are included in their work. We incorporated these $\mathrm{CH}(\mathrm{A})$ formation and consumption rates into our mechanism. In addition, we also computed $\mathrm{CH}(\mathrm{A})$ with GRI3.0+CL. The resulting $\mathrm{CH}(\mathrm{A})$ mole fractions are plotted in Figures 6 and 7 . With the same $\mathrm{CH}(\mathrm{A})$ formation and consumption rates, both mechanism predicts some differences in the $\mathrm{CH}(\mathrm{A})$ mole fractions. The prediction of our mechanism is about 1.5 times lower at $\phi=1.4-1.6$ (and 2.5 times higher at $\phi=1.0$ ) than the experiments, whereas the $\mathrm{CH}(\mathrm{A})$ concentrations are about 3 times smaller than the measured mole fractions when using the GRI3.0+CL mechanism (Fig.7).

For $\mathrm{CH}^{*}$ formation, $\mathrm{C}_{2} \mathrm{H}_{2}, \mathrm{C}_{2} \mathrm{H}$, and $\mathrm{C}_{2}$ are the precursors and their measurements in flames are not abundant in literature. For the flames pre- 


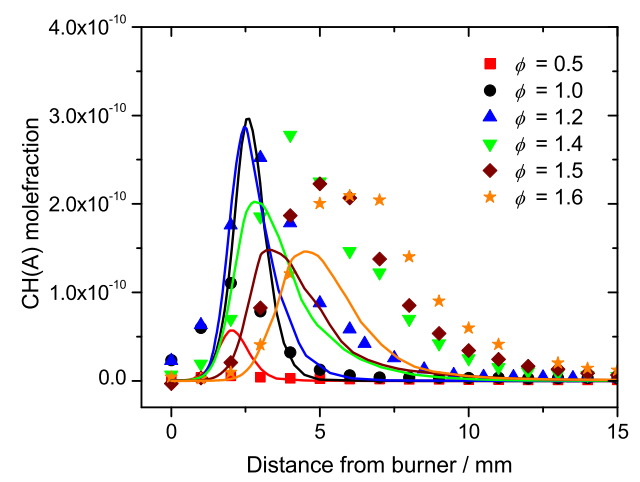

Fig. 6 Comparison of measured and calculated $\mathrm{CH}(\mathrm{A})$ mole fraction profiles at different fuel stoichiometries. The premixed $\mathrm{CH}_{4}-\mathrm{O}_{2}$-Ar flame conditions are as presented in Table 1. Symbols: experiment, line: simulation with mechanism from present work.

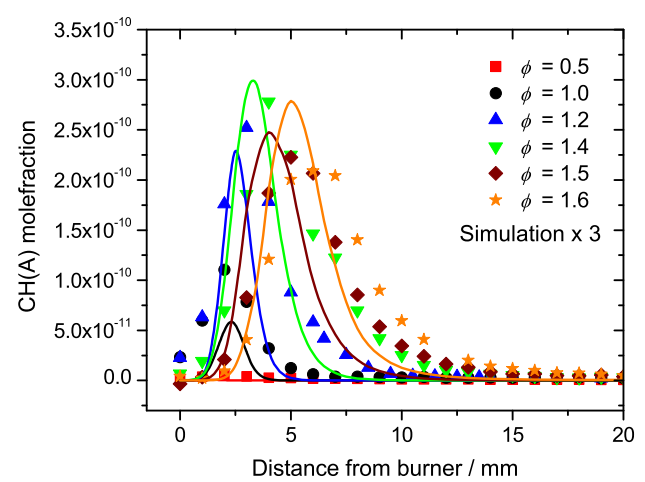

Fig. 7 Comparison of measured and predicted $\mathrm{CH}(\mathrm{A})$ mole fraction simulated with GRI3.0+CL at different fuel stoichiometries. The premixed $\mathrm{CH}_{4}-\mathrm{O}_{2}-\mathrm{Ar}$ flame conditions are as presented in Table 1. Symbols: experiment, line: simulations multiplied by factor of three.

sented in Fig. 6, the difference in concentrations of $\mathrm{C}_{2} \mathrm{H}$ and $\mathrm{C}_{2}$ predicted by both mechanisms are shown in Table 2 . Our mechanism overpredicts $\mathrm{C}_{2} \mathrm{H}$ whereas GRI-mech 3.0 overpredicts the $\mathrm{C}_{2}$ concentrations. As $\mathrm{C}_{2} \mathrm{H}$ is an important precursor, the correct prediction of $\mathrm{CH}^{*}$ is challenging as no data is available for its validation.

Quantitative information on $\mathrm{C}_{2}$ is available from Köhler et al. [21], who measured $\mathrm{C}_{2}$ in $\mathrm{C}_{3} \mathrm{H}_{6}-\mathrm{O}_{2}$ - $\mathrm{Ar}$ flames. The simulated results at five different stoichiometries $(\phi=1.2,1.5,1.8,2.1$, and 2.3) are presented in Fig. 8. For the fuel stoichiometry of 1.2 and 1.5 , the $\mathrm{C}_{2}$ concentrations are overpredicted by factor of 6 and 3 respectively. Whereas at $\phi=1.8-2.3$ they are twice higher than the measurements. Although the concentrations of $\mathrm{C}_{2}$ are higher 
Table 2 Prediction of ground state $\mathrm{C}_{2} \mathrm{H}, \mathrm{C}_{2}$ with GRI-mech 3.0. and mechanism from present work.

\begin{tabular}{ccccc}
\hline$\phi$ & \multicolumn{2}{c}{ peak $\mathrm{C}_{2} \mathrm{H}$ mole fraction } & \multicolumn{2}{c}{ peak $\mathrm{C}_{2}$ mole fraction } \\
& present work & GRI-mech 3.0 & present work & GRI-mech 3.0 \\
\hline 1.2 & $6.6 \times 10^{-6}$ & $1.3 \times 10^{-6}$ & $5.4 \times 10^{-8}$ & $9.6 \times 10^{-8}$ \\
1.6 & $1.8 \times 10^{-5}$ & $1.0 \times 10^{-5}$ & $1.0 \times 10^{-7}$ & $5.2 \times 10^{-7}$ \\
\hline \hline
\end{tabular}

in case of $\phi=1.2$ and $\phi=1.5$, the shape of the profile is in very good agreement compared to the simulations presented in Köhler et al. [21].

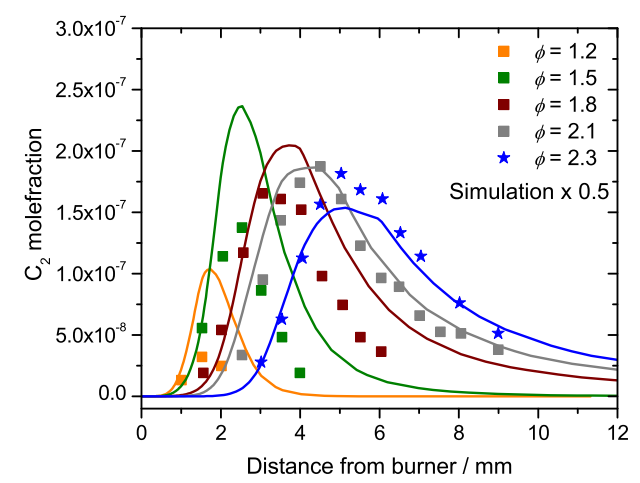

Fig. 8 Absolute $\mathrm{C}_{2}$ mole fractions measured and simulated for various propene$\mathrm{O}_{2}$-Ar flames at 0.05 bar pressure. Symbols: experiment [21], lines: simulations divided by factor of two.

The precursor acetylene has recently been measured in methane-air diffusion flames at various strain rates in Wagner et al. [50]. The results are summarized here in Table 3. The peak position and the absolute values of the predicted $\mathrm{C}_{2} \mathrm{H}_{2}$ are in very good agreement with the measurements. Minor differences between simulated and measured mole fractions are within the uncertainty limits of experiments. For comparison, GRI-mech 3.0 also shows similar results with about $15 \%$ higher values of acetylene concentration at lower strain rates $\left(\mathrm{a}=100,150 \mathrm{~s}^{-1}\right)$.

Both mechanisms predict acetylene quite well. Therefore, the difference in $\mathrm{C}_{2} \mathrm{H}$ and $\mathrm{C}_{2}$ concentration produces variations in the prediction of $\mathrm{CH}(\mathrm{A})$ concentrations. At lean and stoichiometric conditions $\mathrm{C}_{2}$ concentration are two to three orders of magnitude lower than seen at richer condition. Therefore, reaction (R15) is not important at these conditions. Under richer fuel conditions, both $\mathrm{C}_{2} \mathrm{H}$ and $\mathrm{C}_{2}$ concentrations are sufficient to contribute to $\mathrm{CH}(\mathrm{A})$ formation. Correct prediction of $\mathrm{C}_{2} \mathrm{H}$ and $\mathrm{C}_{2}$ in future mechanisms will further refine the reaction rates and their relative branching ratios. 
Table 3 Comparison of predicted and measured $\mathrm{C}_{2} \mathrm{H}_{2}$ maximum mole fractions in $\mathrm{CH}_{4}$-air diffusion flames. Measurements from [50]. Values in brackets are simulated results with GRI-mech 3.0.

\begin{tabular}{|c|c|c|c|c|}
\hline \multirow[t]{2}{*}{$\mathrm{a}, \mathrm{s}^{-1}$} & \multicolumn{2}{|c|}{ peak $\mathrm{C}_{2} \mathrm{H}_{2}$ mole fraction $\left(\times 10^{-3}\right)$} & \multicolumn{2}{|c|}{ peak position, $\mathrm{mm}$} \\
\hline & Experiment(uncertainty) & Simulation & Experiment & Simulation \\
\hline 100 & $8.3 \pm 10 \%$ & $7.9(10.1)$ & 2.4 & $2.4(2.3)$ \\
\hline 150 & $8.3 \pm 14 \%$ & $7.8(9.5)$ & 1.9 & $1.9(1.9)$ \\
\hline 200 & $8.3 \pm 18 \%$ & $8.0(9.6)$ & 1.7 & $1.7(1.7)$ \\
\hline 300 & $7.6 \pm 19 \%$ & $7.3(7.1)$ & 1.5 & $1.5(1.4)$ \\
\hline
\end{tabular}

5.1.3 $\mathrm{CH}(\mathrm{B})$ The $\mathrm{CH}(\mathrm{B})$ state has been studied less extensively. Crosley et al. [10] have discussed the possibility of two different mechanisms for the $\mathrm{CH}(\mathrm{A})$ and $\mathrm{CH}(\mathrm{B})$ states based on the fact that the difference in both profiles are not the result of variations in the emission quantum yield. They did not, however, suggest actual reactions leading to the formation of the $\mathrm{CH}(\mathrm{B})$ state. In our measurements, the profile shapes and the peak positions of both $\mathrm{CH}(\mathrm{A})$ and $\mathrm{CH}(\mathrm{B})$ states are similar, except for the ratio of the peak mole fractions of both states $\mathrm{CH}(\mathrm{A}) / \mathrm{CH}(\mathrm{B})$ which is found to be about 9 for all stoichiometries from $\phi=1.0$ to 1.6. Therefore, it seems likely that both electronic states are produced by the same reactions.

The radiative lifetime and collisional quenching rates of $\mathrm{CH}(\mathrm{B})$ have been studied in the literature $[7,8,33]$. Rensberger et al. [33] have concluded that the B-state of $\mathrm{CH}$ is removed about $70 \%$ faster than the A-state in their low pressure flame. However, since the radiative lifetime of $\mathrm{CH}(\mathrm{B})$ is about $60 \%$ shorter than the A-state, both effects cancel each other. Cooper et al. [8,9] and Chen et al. [7], measured total collisional removal of $\mathrm{CH}(\mathrm{B})$ at room temperature for $\mathrm{M}=\mathrm{Ar}, \mathrm{O}_{2}, \mathrm{H}_{2}, \mathrm{CO}_{2}, \mathrm{CH}_{4}, \mathrm{C}_{2} \mathrm{H}_{4}, \mathrm{C}_{2} \mathrm{H}_{6}$, and $\mathrm{C}_{3} \mathrm{H}_{8}$ and for $\mathrm{M}=\mathrm{Ar}, \mathrm{O}_{2}$, respectively. Their work does not specify separate reaction rates for reactive and non-reactive quenching. Moreover, quenching rates are only measured at room temperature and there is no recommendation of the $\mathrm{CH}(\mathrm{B})$ formation reactions and their rate coefficients. In addition to the collisional quenching, electronic energy transfer (EET) between the $\mathrm{CH}(\mathrm{A})$ and $\mathrm{CH}(\mathrm{B})$ states are studied by Richmond et al. [34] and Crosley et al. [10] where the latter suggested about $20 \%$ of $\mathrm{CH}(\mathrm{B})$ state is transferred to the $\mathrm{CH}(\mathrm{A})$ state.

As a starting point in our calculation, we took the formation reactions rates of the $\mathrm{CH}(\mathrm{B})=\mathrm{CH}(\mathrm{A})$. The quenching rate for $\mathrm{Ar}$ is taken from Chen et al. [7] whereas for $\mathrm{M}=\mathrm{O}_{2}, \mathrm{CO}_{2}$, and $\mathrm{CH}_{4}$ are from studies of Cooper et al. [8]. Since these rates were derived at $295 \mathrm{~K}$, we extrapolated the rate at temperatures where $\mathrm{CH}(\mathrm{B})$ attends its maximum by considering the temperature dependence of $\mathrm{CH}(\mathrm{A})$ state for given collider species. For the quenching of $\mathrm{CH}(\mathrm{B})$ with $\mathrm{M}=\mathrm{CO}, \mathrm{H}_{2}, \mathrm{H}_{2} \mathrm{O}, \mathrm{H}$, and $\mathrm{OH}$, the better known high temperature quenching rates of $\mathrm{CH}(\mathrm{A})$ states were taken and simulations are performed at given experimental condition. It is evident 
from the measured intensities that the $\mathrm{CH}(\mathrm{B})$ state has about 9 times lower maximum intensity at various $\phi=1.0$ to 1.6 , see Table 4 . The rates of all formation reactions were assumed to be $k_{C H(B)}=0.13 \cdot k_{C H(A)}$ and with EET rate of $\mathrm{k}=5.0 \times 10^{7}$ for quenching of $\mathrm{CH}(\mathrm{B})$ state to $\mathrm{CH}(\mathrm{A})$, the experimental $\mathrm{CH}(\mathrm{A})$ to $\mathrm{CH}(\mathrm{B})$ ratios of peak concentrations were reproduced by simulations as shown in Table 4 . The simulated ratio at $\phi=1.0$ is about $29 \%$ higher and at $\phi=1.2$ it is $8 \%$ higher than the experiments. For other fuel stoichiometries, they are within $1-2 \%$ of measured values.

Table 4 Ratio of $\mathrm{CH}(\mathrm{A})$ to $\mathrm{CH}(\mathrm{B})$ maximum mole fraction in $\mathrm{CH}_{4}-\mathrm{O}_{2}$-Ar flames.

\begin{tabular}{lcc}
\hline$\phi$ & & $\mathrm{CH}(\mathrm{A}) / \mathrm{CH}(\mathrm{B})$ \\
& Experiment & Simulation $(\sim 20 \% \mathrm{~B} \rightarrow \mathrm{A})$ \\
\hline 1.0 & 9.28 & 13.09 \\
1.2 & 9.88 & 10.69 \\
1.4 & 9.95 & 9.71 \\
1.5 & 9.15 & 9.35 \\
1.6 & 9.02 & 9.13 \\
\hline \hline
\end{tabular}

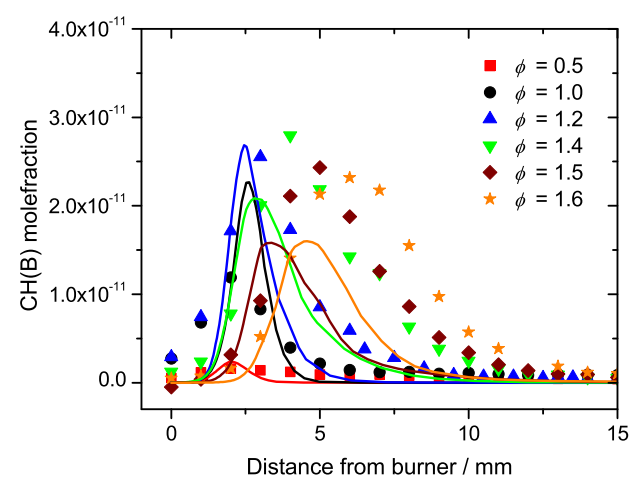

Fig. 9 Comparison of measured and calculated $\mathrm{CH}(\mathrm{B})$ mole fraction profiles at different fuel stoichiometries. The premixed $\mathrm{CH}_{4}-\mathrm{O}_{2}$-Ar flame conditions are as presented in Table 1. Symbols: experiment, line: simulation with mechanism from present work.

The quenching rate of Ar is similar in the studies of Cooper et al. [8,9] and Chen et al. [7] who concluded that the quenching with Ar is negligible. This is also observed in our simulations. The major quencher is $\mathrm{M}=\mathrm{H}_{2}$ ranging from $45 \%(\phi=1.0)$ to $80 \%(\phi=1.6)$. Other quenchers of secondary importance are $\mathrm{M}=\mathrm{CO}, \mathrm{H}_{2} \mathrm{O}$. The electronic energy transfer of $\mathrm{CH}(\mathrm{B})$ to $\mathrm{CH}(\mathrm{A})$ is about $20 \%$. Few studies suggested reactive quenching as possibility 


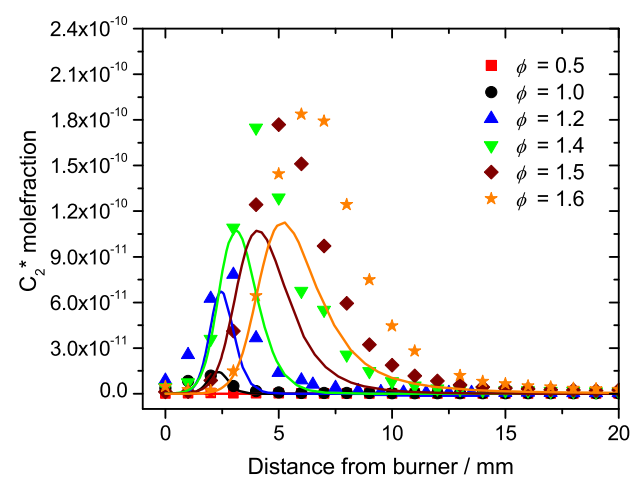

Fig. 10 Comparison of measured and calculated $\mathrm{C}_{2} *$ mole fraction profiles at different fuel stoichiometries. The premixed $\mathrm{CH}_{4}-\mathrm{O}_{2}-\mathrm{Ar}$ flame conditions are as presented in Table 1. Symbols: experiment, line: simulation mechanism from present work.

with some colliders such as $\mathrm{CO}[34], \mathrm{H}_{2}$ [9,34], $\mathrm{CH}_{4}$ [9]. In our work, we only assume non-reactive quenching considering the lack of information on species formed due to reactive quenching. The resulting $\mathrm{CH}(\mathrm{B})$ profiles are seen in Fig. 9 where the peak mole fractions are fairly well reproduced at different stoichiometry.

5.1.4 $C_{2}{ }^{*}$ It has been suggested that formation of electronically excited $\mathrm{C}_{2} *$ is mainly due to the reaction of $\mathrm{C}_{3}+\mathrm{O}(\mathrm{R} 43)$ and the reaction of singlet $\mathrm{CH}_{2}$ with a carbon atom (R42). For the calculations of $\mathrm{C}_{2}{ }^{*}$, we used the $k$ values of (R42) and (R43) from the recommendation of Smith et al. [40]. Figure 10 shows the comparison of $\mathrm{C}_{2}{ }^{*}$ with measured profiles at different fuel stoichiometries. A negligible amount of $\mathrm{C}_{2}{ }^{*}$ is formed at lean condition. At stoichiometric condition, about an order of magnitude lower $\mathrm{C}_{2} *$ is seen in comparison to rich flames. At $\phi=1.2$, the predictions of simulated $\mathrm{C}_{2}$ * mole fractions are similar to the measurements, the predicted peak $\mathrm{C}_{2}$ * values at rich conditions $(\phi=1.4-1.6)$ are about 1.5 times smaller to the measured value. Also at $\phi=1.2-1.6$, the simulated profiles decay faster compared to the measurements.

The $\mathrm{C}_{2}{ }^{*}$ profiles obtained with our mechanism underpredict the maximum concentrations by factor of 1.5 for $\phi=1.4-1.6$ flames. Smith et al. [40] suggested overall quenching rate of $\mathrm{C}_{2}{ }^{*}$ and no information is available for the quenching of individual quencher. Therefore, it is possible that our faster quenching rates consumes more $\mathrm{C}_{2}{ }^{*}$. A test calculation considering only major quencher $\mathrm{M}=\mathrm{O}_{2}, \mathrm{CO}_{2}, \mathrm{H}_{2} \mathrm{O}$, and Ar showed that although there was increase in $\mathrm{C}_{2}$ * concentration which is apparent, the peak position and the decay were unaffected. Due to still inaccurate $\mathrm{C}_{3}$ chemistry, the rates of both $\mathrm{C}_{2}$ * formation reaction cannot be accurately derived to reproduce the measurements. 


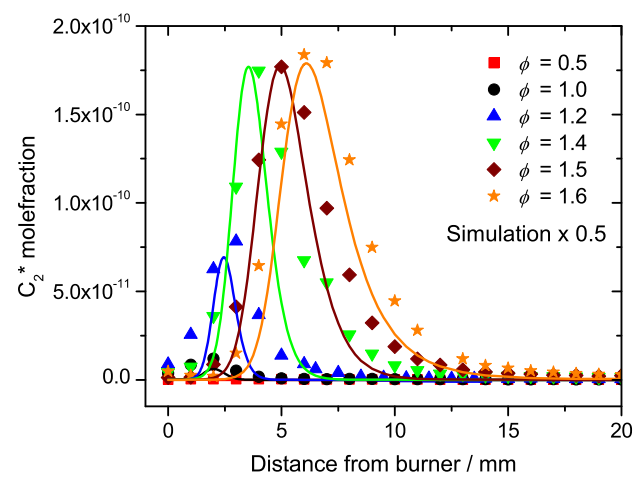

Fig. 11 Comparison of measured and predicted $\mathrm{C}_{2} *$ mole fraction simulated with GRI3.0+CL at different fuel stoichiometries. The premixed $\mathrm{CH}_{4}-\mathrm{O}_{2}-\mathrm{Ar}$ flame conditions are as presented in Table 1. Symbols: experiment, line: simulations divided by factor of two.

A similar comparison made with the $\mathrm{C}_{2} *$ concentrations simulated with GRI3.0+CL showed a twofold overprediction at all rich stoichiometries (Fig. 11). The prediction of $\mathrm{C}_{2}{ }^{*}$ depends on the ground state ${ }^{1} \mathrm{CH}_{2}$ and $\mathrm{C}_{3}$. McIlroy et al. [51] measured ${ }^{1} \mathrm{CH}_{2}$ in three low pressure methane- $\mathrm{O}_{2}$-Ar premixed flames. The experimentally measured ${ }^{1} \mathrm{CH}_{2}$ concentrations are very well reproduced by the simulations, except at $\phi=1.6$, with our mechanism [20] and GRI-mech 3.0 as shown in Fig. 12. The tricarbon $\mathrm{C}_{3}$ cannot be validated at flame condition since there are no measurements available. The ground state $\mathrm{C}_{2}$ is the precursor to the $\mathrm{C}_{3}$ formation, and the reaction rates of these species are just scientific guesses in most cases due to lack of rate data or are available only at room temperatures. It is likely that during the validation of $\mathrm{C}_{2}$ any discrepancies between measurement and simulations are reduced by changing the rates involving reactions of $\mathrm{C}_{3}$. Therefore, both GRI3.0+CL and our mechanism show discrepancies with the measurement and require refinement of the reaction rates and the mechanisms to reproduce the measured data.

\subsection{Effect of hydrogen addition}

Hydrogen-enhanced fuels, which may be produced by steam reforming of natural gas, have been suggested as alternatives to existing fuels because of their increased efficiency and significantly reduced emissions. Therefore, we examined the effect of hydrogen addition to the studied fuel at two fuel stoichiometries. Eight different $\mathrm{CH}_{4}-\mathrm{O}_{2}$-Ar flames with varying hydrogen content $(=10,20,30,50 \%)$ are studied to see its effect on the formation of excited species. The fuel conditions are stoichiometric $(\phi=1.0)$ and rich $(\phi$ $=1.5)$. 


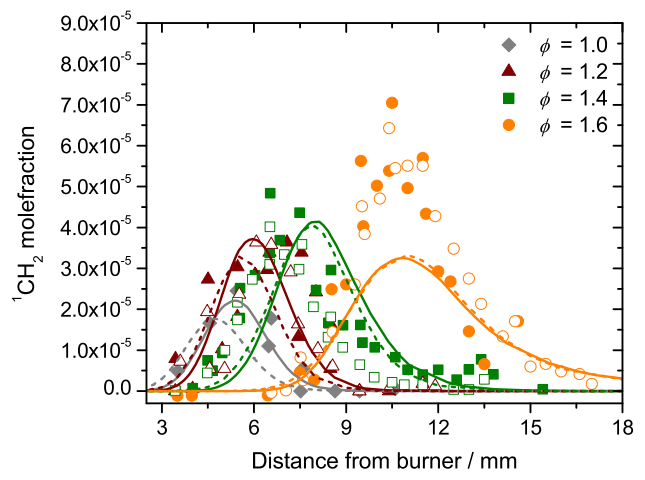

Fig. 12 Measured and simulated singlet $\mathrm{CH}_{2}$ concentrations for $\mathrm{CH}_{4}-\mathrm{O}_{2}-\mathrm{Ar}$ flames at four fuel stoichiometries $(\phi=1.0,1.2,1.4$, and 1.6). Experiments: McIlroy [51]. Symbols: experiments with two different spectral lines ${ }^{r} \mathrm{Q}_{0.7}$ and ${ }^{r} \mathrm{Q}_{0.4}$ as described in Fig. 4 of [51], line: simulation present work, dashed line: simulation with GRI-mech 3.0 [37].

The measurements and simulations show that for the case of $\mathrm{OH}^{*}$, there is a significant decrease in the peak concentration with increasing hydrogen content in the fuel. For stoichiometric flame, at $\mathrm{H}_{2}=50 \%$, there is a threefold decrease in $\mathrm{OH}^{*}$ concentration compared to a pure methane flame $\left(\mathrm{H}_{2}\right.$ $=0 \%$ ). The major contributor to $\mathrm{OH}^{*}$ formation at all conditions is reaction (R2) from $\mathrm{CH}+\mathrm{O}_{2}$ and the three-body reaction (R1) has no contribution to $\mathrm{OH}^{*}$ formation. The ground state $\mathrm{CH}$ concentrations in stoichiometric fuel mixture shows a slow decrease in the peak concentration when the $\mathrm{H}_{2}$ content in the fuel increases from 0 to $50 \%$, whereas at fuel rich condition it increases from $\mathrm{H}_{2}=0$ to $30 \%$ and decreases from $\mathrm{H}_{2}=30$ to $50 \%$. This trend is also seen in $\mathrm{OH}^{*}$ peak concentrations as shown in Fig. 13a.

Similar to $\mathrm{OH}^{*}, \mathrm{CH}(\mathrm{A})$ concentrations decrease with an increase of hydrogen in the fuel (Fig. 13b). The maximum effect of hydrogen addition is one order of magnitude between the concentrations of $\mathrm{CH}(\mathrm{A})$ without $\mathrm{H}_{2}$ dilution and $\mathrm{H}_{2}=50 \%$. For the given reactions in the mechanism, about $60 \%$ of $\mathrm{CH}(\mathrm{A})$ is formed by reaction of $\mathrm{C}_{2} \mathrm{H}+\mathrm{O}_{2}(\mathrm{R} 13)$ at $\phi=1.0$. At rich conditions $(\phi=1.5)$ its contribution increases to about $75-90 \%$. The remaining $\mathrm{CH}(\mathrm{A})$ is formed by (R14). The (R15) contributes only minor about $5 \%$ to $\mathrm{CH}(\mathrm{A})$ formation.

Figure 13c shows simulated and measured peak intensities for different hydrogen-diluted mixtures where the $\mathrm{CH}(\mathrm{B})$ peak values decreases with added hydrogen. In stoichiometric and fuel-rich mixture, $\mathrm{CH}(\mathrm{B})$ is mainly (60-80\%) formed from reaction ( $\mathrm{R} 27)$.

At stoichiometric condition both formation reactions play nearly equal role in forming $\mathrm{C}_{2}{ }^{*}$, however, at rich condition the reaction $\mathrm{C}_{3}+\mathrm{O}$ remains a major contributor (60-80\%). In Fig. $13 \mathrm{~d}$, at $\phi=1.0$, the $\mathrm{C}_{2} *$ peak concentration decreases five times when $\mathrm{H}_{2}$ content is varied from 0 to $50 \%$ 

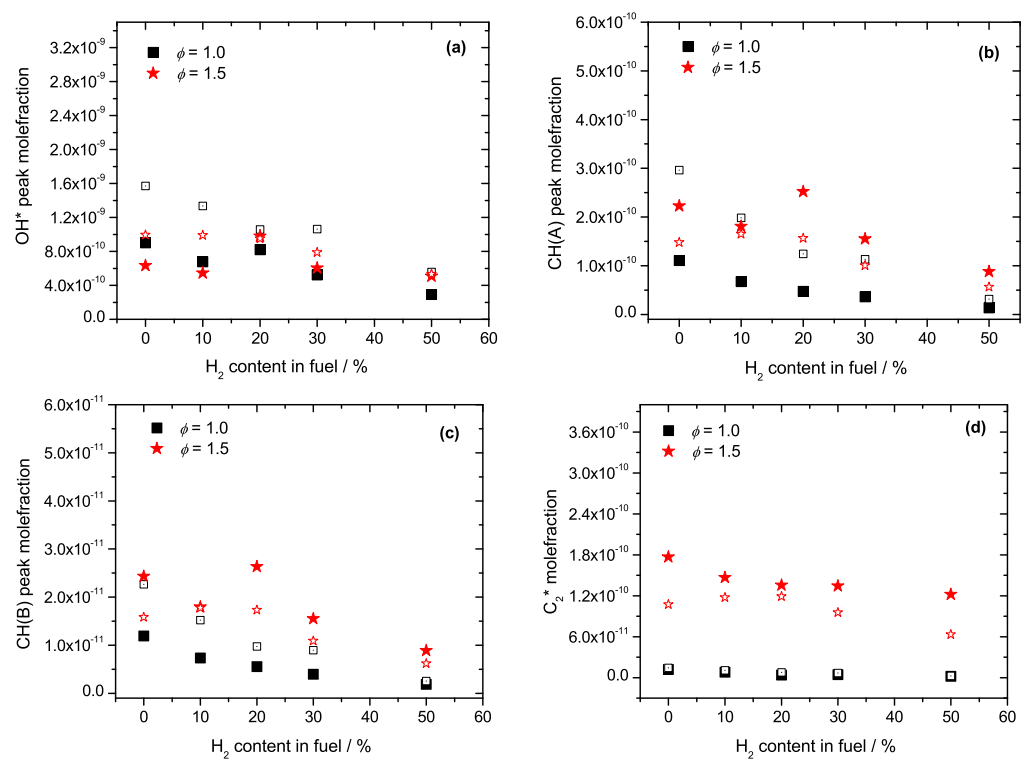

Fig. 13 Peak concentrations and intensities of premixed $\mathrm{CH}_{4}-\mathrm{H}_{2}-\mathrm{O}_{2}-\mathrm{Ar}$ flames. Closed symbols: experiment, open symbols: simulations. Lines are polynomial fits to the simulated data points.

whereas in rich mixture $\mathrm{C}_{2}{ }^{*}$ peak values has only marginal difference from $\mathrm{H}_{2}$ addition.

For all excited species, at $\phi=1.0$ the peak position is independent of the hydrogen content, whereas under fuel-rich condition $(\phi=1.5)$ the diluted mixtures peak closer to the burner surface.

\section{Chemiluminescence and heat release}

Several flame observables such as $\mathrm{CH}, \mathrm{CH}_{2} \mathrm{O}$ have already been studied and discussed as marker of heat release $[30,45]$. It is known from the literature that the appearance of formaldehyde $\left(\mathrm{CH}_{2} \mathrm{O}\right)$ is indicative of the peak heat release location. Its concentration product with $\mathrm{OH}\left(\left[\mathrm{CH}_{2} \mathrm{O}\right][\mathrm{OH}]\right)$ is also studied as an indicator for the heat release location [30]. The $\mathrm{CH}$ radical in its ground state appears in the narrow flame front region and is found an adequate indicator for heat release position in hydrocarbon oxidation [45]. Chemiluminescent species are also studied as important intermediates that characterize the reaction zone due to their appearance in the flame front and are studied in combustion systems $[23,30,32]$.

A comparison of the displacement of the peak excited species location from the peak heat release location to see the potential of chemiluminescence as heat release marker has been performed in [18]. With the present mechanism given in Table 5, a numerical experiment is performed in a premixed 


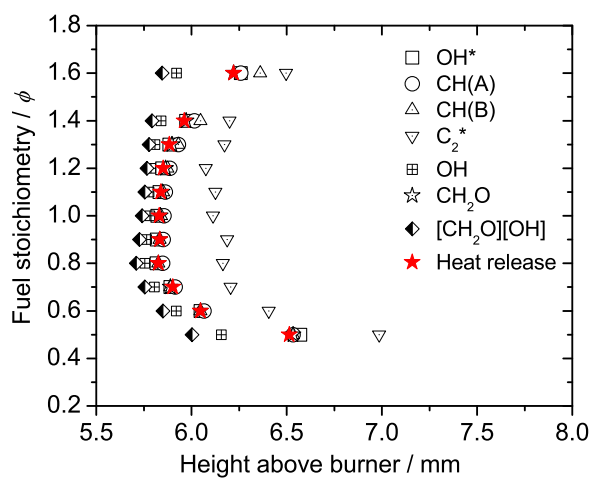

Fig. 14 Comparison of the location of peak heat release with the location of peak excited species and ground state species $\left(\mathrm{CH}_{2} \mathrm{O}\right.$ and $\left.\mathrm{OH}\right)$ at different fuel stoichiometries. The mixture composition of the $\mathrm{CH}_{4}$ /air flames are at $298 \mathrm{~K}$ initial temperature and 1 bar pressure.

methane-air-flame with fuel stoichiometry varying from lean $(\phi=0.5)$ to rich $(\phi=1.6)$ condition. The methane-air mixtures are at $298 \mathrm{~K}$ initial temperature and one bar pressure.

The location of the peak heat release and peak species mole fractions, as shown in Figure 14, are plotted for different fuel equivalence ratios of $\mathrm{CH}_{4}$-air mixtures. The location of $\mathrm{CH}_{2} \mathrm{O}$ and $\left[\mathrm{CH}_{2} \mathrm{O}\right][\mathrm{OH}]$ are also shown in addition to the peak location of excited species and heat release to see the prediction of excited state species compared to ground state species. The appearance of formaldehyde and $\mathrm{OH}^{*}$ are found closest to the heat release location. The location of peak $\mathrm{OH}^{*}$ is closely followed by the $\mathrm{CH}(\mathrm{A})$ and $\mathrm{CH}(\mathrm{B})$ emissions and largest deviation from heat release location is found with $\mathrm{C}_{2}{ }^{*}$ which is about 0.2 to $0.4 \mathrm{~mm}$. In the intermediate fuel stoichiometries ( $\phi=0.6$ to 1.2 ), the maximum deviation of excited species $\left(\mathrm{OH}^{*}, \mathrm{CH}(\mathrm{A})\right.$, and $\left.\mathrm{CH}(\mathrm{B})\right)$ from the heat release location is about $0.02 \mathrm{~mm}$. Under rich conditions $(\phi>1.2)$, the displacement increases up to $0.09 \mathrm{~mm}$ which is still smaller than minimum displacement of $\mathrm{C}_{2} *(0.22 \mathrm{~mm}$ at $\phi$ $=1.2$ ). The appearance of $\left[\mathrm{CH}_{2} \mathrm{O}\right][\mathrm{OH}]$ product concentration is further, at least $0.08 \mathrm{~mm}$, away from heat release location. The difference between different species locations increases at boundary value of $\phi$ i.e., at 0.5 and 1.6, and it decreases for intermediate stoichiometries. The trend of such variation in displacement with fuel stoichiometry is due to the change in reaction zone thickness.

From this numerical study it can be seen that $\mathrm{OH}^{*}, \mathrm{CH}(\mathrm{A})$, and $\mathrm{CH}(\mathrm{B})$ are found closest to the peak heat release location and give results similar to the peak location of formaldehyde $\left(\mathrm{CH}_{2} \mathrm{O}\right)$. The difference in location of $\mathrm{OH}^{*}$ and $\mathrm{CH}^{*}$ (in both states) is not significant (about 0.01-0.02 mm) and therefore can also be used as heat release marker. The position of $\mathrm{C}_{2}$ * appears much later in the flame and is therefore, under the given conditions, not suitable as heat release marker. The difference in the $\mathrm{OH}^{*}$ and $\mathrm{CH}^{*}$ 
positions from the peak heat release location are relatively small compared to the resolution of measurement techniques (few millimeters for laboratory flame). These results show that $\mathrm{OH}^{*}$ and $\mathrm{CH}^{*}$ are good markers for the heat release zone for the flames investigated. It should be pointed out that both the spatial and the temporal resolution of chemiluminescence measurements will always be inferior to that of laser-based measurements, which might limit the value of chemiluminescence measurements in turbulent flames. Future studies at practical conditions have to provide more insight into the potential of chemiluminescence as heat release marker in turbulent systems.

\section{Conclusion}

Spatially-resolved chemiluminescence has been measured in several laminar, premixed, flat $\mathrm{CH}_{4}-\mathrm{O}_{2}-\mathrm{Ar}$ and $\mathrm{CH}_{4}-\mathrm{H}_{2}-\mathrm{O}_{2}$ - Ar flames at 0.05 bar. Under these conditions, the strongest chemiluminescent emissions originate from the $\mathrm{OH}\left(\mathrm{A}^{2} \Sigma^{+}\right), \mathrm{CH}\left(\mathrm{A}^{2} \Delta\right)$ and $\mathrm{CH}\left(\mathrm{B}^{2} \Sigma^{-}\right)$states and, in rich flames, the $\mathrm{C}_{2}$ (d-a) Swan bands. Other interfering emissions (especially from $\mathrm{CO}_{2}{ }^{*}$, which might contribute in turbulent flames) are not present.

A reaction mechanism for the prediction the $\mathrm{OH}^{*}, \mathrm{CH}^{*}$ (in $\mathrm{A}-$ and $\mathrm{B}-$ state) and $\mathrm{C}_{2} *$ in lean to fuel-rich stoichiometries has been developed using a previously developed $\mathrm{C}_{1}-\mathrm{C}_{4}$ hydrocarbon oxidation mechanism as a basis. The mechanism of the chemiluminescent species requires an additional sub-scheme predicting $\mathrm{C}_{2}$ and $\mathrm{C}_{3}$ species which is not part of the original mechanism. Due to low concentrations in flames, these C-containing species are difficult to measure and the lack of reliable rate data makes the mechanism development challenging. Our earlier study [20] has shown that the correct prediction of excited species requires good validation of precursor chemistry which forms excited species.

The prediction of excited species concentrations in $\mathrm{CH}_{4}-\mathrm{O}_{2}-\mathrm{Ar}$ and $\mathrm{CH}_{4}{ }^{-}$ $\mathrm{H}_{2}-\mathrm{O}_{2}$-Ar flames is found in fairly good agreement with the measurements. This is true especially for $\mathrm{OH}^{*}$, where the reactions are relatively well understood. $\mathrm{CH}^{*}$ prediction is, however, not as reliable. Assessing the relative importance of the three recommended reactions for $\mathrm{CH}^{*}$ formation remains problematic - mainly because there are too many degrees of freedom arising from acetylene and $\mathrm{C}_{2}$ chemistry. Based on the measured intensities, we initiated the prediction of $\mathrm{CH}^{*}$ in both $\mathrm{A}$ and $\mathrm{B}$ states. So far, no distinct characteristics could be identified for the $\mathrm{CH}(\mathrm{B})$ state, except its lower intensities compared to the $\mathrm{CH}(\mathrm{A})$ state. The prediction of $\mathrm{C}_{2}$ * is less complicated compared to $\mathrm{CH}^{*}$. However, it is also suffers from uncertainties in the $\mathrm{C}_{2}$ chemistry.

Overall, our mechanism shows fairly good predictive capabilities. Comparison with GRI-mech 3.0 with extended chemiluminescence model (GRI3.0+CL) from Smith el al. [38-40] shows, that the GRI3.0+CL would require refinement in their rate values, especially with respect to the $\mathrm{CH}^{*}$ and $\mathrm{C}_{2}{ }^{*}$ prediction. 
For a further test of the mechanism, absolute concentrations measurements of chemiluminescent species would be of great interest. Additionally, simultaneous quantitative measurement of important precursors such as $\mathrm{C}_{2} \mathrm{H}, \mathrm{C}_{2}$, and $\mathrm{C}_{3}$ [4], which are of minor importance for the overall combustion process, would facilitate further development of the mechanism.

Acknowledgements The authors thank Katharina Kohse-Höinghaus for support and helpful discussions. Deutsche Forschungsgemeinschaft (DFG) has funded this work under contracts RI 839/4-2, KO 1363/21-2, PAK 116/1 and 116/2 and SFB 686 TP C5.

\section{References}

1. D. L. Baulch, C. T. Bowman, C. J. Cobos, R. A. Cox, Th. Just, J. A. Kerr, M. J. Pilling, D. Stocker, J. Troe, W. Tsang, R. W. Walker, J. Warnatz, J. Phys. Chem. Ref. Data, 34, (2005) 757.

2. F. Biagioli, F. Göthe, B. Schuermans, Exp. Thermal Fluid Sci. 32, (2008) 1344 .

3. M. Bozkurt, M. Fikri, C. Schulz, Appl. Phys. B: Lasers and Optics, (2012) in press.

4. A. Brockhinke, M. Letzgus, S. Rinne, K. Kohse-Höinghaus, J. Phys. Chem. A, 110, (2006) 3028.

5. E. Goos, A. Burcat, B. Ruscic, New NASA Thermodynamic Polynomials Database With Active Thermochemical Tables updates, Report ANL 05/20 TAE 960 (2011).

6. S. Candel, Proc. Combust. Inst. 29, (2002) 1.

7. C. Chen, Y. Sheng, S. Yu, X. Ma, J. Chem. Phys., 101, (1994) 5727.

8. J. Cooper, J. Whitehead, J. Chem. Soc. Faraday trans., 88, (1992) 2323.

9. J. Cooper, J. Whitehead, J. Phys. Chem., 98, (1994) 8274.

10. D.R. Crosley, K.J. Rensberger, R.A. Copeland, Selectivity in Chemical Reactions (ed. J.C. Whitehead, Kluwer, Dordrecht p.543, 1988).

11. A.G. Gaydon, The spectroscopy of flames (Wiley, New York 1974).

12. P. Gopalakrishnan, M.K. Bobba, J.M. Seitzman, Proc. Combust. Inst. 31, (2007) 3401.

13. L. Haber, U. Vandsburger, Combust. Sci. Technol., 175, (2003) 1859.

14. J. Hall, J. Vries, A. Amadio, E. Petersen, Aerospace Sciences Meeting and Exhibit, 43, (2005) AIAA 2005-1318.

15. J. Hall, E. Petersen, Int. J. Chem. Kinet., 38, (2006) 714.

16. C. Hand, G. Kistiakowsky, J. Chem. Phys., 37, (1962) 1239.

17. Y. Hardalupas, M. Orain, C.S. Panoutsos, A.M.K.P. Taylor, J. Olofsson, H. Seyfried, M. Richter, J. Hult, M. Aldén, F. Hermann, J. Klingmann, Appl. Thermal Eng. 24, (2004) 1619.

18. T. Kathrotia, U. Riedel, J. Warnatz, $4^{\text {th }}$ European Combustion Meeting, (2009) Paper 2.

19. T. Kathrotia, M. Fikri, M. Bozkurt, M. Hartmann, U. Riedel, C. Schulz, Combust. Flame, 157, (2010) 1261.

20. T. Kathrotia, Ph.D Thesis, Universität Heidelberg (2011). Available online: http://archiv.ub.uni-heidelberg.de/volltextserver/volltexte/2011/12027/ 
21. M. Köhler, A. Brockhinke, M. Braun-Unkhoff, K. Kohse-Höinghaus, J. Phys. Chem. A, 114, (2010) 4719.

22. K. Kohse-Höinghaus, A. Brockhinke, Combust., Expl., Shock Waves, 45, (2009) 349.

23. J. Kojima, Y. Ikeda, T. Nakajima, Proc. Combust. Inst., 28, (2000) 1757.

24. J. Kojima, Y. Ikeda, T. Nakajima, Combust. Flame. 140, (2005) 34.

25. S. Krishnamachari, H. Broida, J. Chem. Phys., 34, (1961) 1709.

26. J. Luque, D.R. Crosley, LIFBASE (version 2.0.6), Report MP 99-009, SRI International, Menlo Park, CA, (1999).

27. U. Maas, Appl. Math., 40, (1995) 249.

28. U. Maas, J. Warnatz, Combust. Flame, 74, (1988) 53.

29. J. Miller, C. Melius, Combust. Flame, 91, (1992) 21.

30. H. Najm, P. Paul, C. Mueller, P. Wyckoff, Combust. Flame, 113, (1998) 312.

31. V. Nori, J. Seitzman, Proc. Combust. Inst., 32, (2009) 895.

32. C. Panoutsos, Y. Hardalupas, A.M.K.P. Taylor, Combust. Flame, 156, (2009) 273.

33. K. Rensberger, M. Dyer, R. Copeland, Appl. Opt., 27, (1988) 3679.

34. G. Richmond, M.L. Costen, K.G. McKendrick, J. Phys. Chem. A, 109, (2005) 542 .

35. M. Savadatti, H. Broida, J. Chem. Phys., 45, (1966) 2390.

36. K. Schofield, M. Steinberg, J. Phys. Chem. A, 111, (2007) 2098.

37. G.P. Smith, D.M. Golden, M. Frenklach, N.W. Moriarty, B. Eiteneer, M. Goldenberg, C.T. Bowmann, R.K. Hanson, S. Song, W.C. Gardiner Jr., V.V. Lissianski, Z. Qin, GRI-mech 3.0, University of California, Berkeley, CA. (1999).

38. G. Smith, J. Luque, C. Park, J. Jeffries, D. Crosley, Combust. Flame, 131, (2002) 59.

39. G. Smith, C. Park, J. Luque, Combust. Flame, 140, (2005) 385.

40. G. Smith, C. Park, J. Schneiderman, J. Luque, Combust. Flame, 141, (2005) 66 .

41. U. Struckmeier, P. Oßwald, T. Kasper, L. Böhling, M. Heusing, M. Köhler, A. Brockhinke, K. Kohse-Höinghaus, Z. Phys. Chem. 223, (2009) 503.

42. C.A. Taatjes, N. Hansen, D.L. Osborn, K. Kohse-Höinghaus, T.A. Cool, P.R. Westmoreland, Phys. Chem. Chem. Phys. 10, (2008) 20.

43. M. Tamura, P. Berg, J. Harrington, J. Luque, J. Jeffries, G. Smith, D. Crosley, Combust. Flame, 114, (1998) 502.

44. T. Turanyi, Comput. Chem., 14, (1990) 253.

45. C.M. Vagelopoulos, J.H. Frank, Proc. Combust. Inst. 30, (2005) 241.

46. B.A. Williams, L. Pasternack, Combust. Flame, 111, (1997) 87.

47. J.W. Thoman Jr., A.J. McIlroy, Phys. Chem. A, 104, (2000) 4953.

48. P. Nau, J. Krüger, A. Lackner, M. Letzgus, A. Brockhinke, Appl. Phys. B: Lasers and Optics, (2012) in press.

49. P.H. Paul, J.L. Durant Jr., J.A. Gray, J. Chem. Phys., 102, (1955) 8378.

50. S. Wagner, M. Klein, T. Kathrotia, U. Riedel, T. Kissel, A. Dreizler, V. Ebert, Appl. Phys. B: Lasers and Optics, (2012) in press.

51. A. McIlroy, Chem. Phys. Lett., 296, (1998) 151.

Table 5: Reaction mechanism of chemiluminescent species. 


\begin{tabular}{|c|c|c|c|c|c|}
\hline No. & Elementary reaction & $\begin{array}{l}A \\
\mathrm{~cm}, \mathrm{~mol}, \mathrm{~s}\end{array}$ & $\begin{array}{l}n \\
{[-]}\end{array}$ & $\begin{array}{l}E \\
\mathrm{~kJ} \cdot \mathrm{mol}^{-1}\end{array}$ & Ref. \\
\hline \multicolumn{6}{|c|}{ Chemiluminescence reactions } \\
\hline \multicolumn{6}{|c|}{$\underline{\mathrm{OH}^{*} \text { reactions }}$} \\
\hline $\mathrm{R} 1$ & $\mathrm{H}+\mathrm{O}+\mathrm{M}=\mathrm{OH}^{*}+\mathrm{M}$ & $1.50 \cdot 10^{13}$ & 0.0 & 25.0 & {$[19]$} \\
\hline $\mathrm{R} 2$ & $\mathrm{CH}+\mathrm{O}_{2}=\mathrm{OH}^{*}+\mathrm{CO}$ & $1.80 \cdot 10^{11}$ & 0.0 & 0.0 & {$[38]$} \\
\hline R3 & $\mathrm{OH}^{*}=\mathrm{OH}$ & $1.45 \cdot 10^{06}$ & 0.0 & 0.0 & [43] \\
\hline R4 & $\mathrm{OH}^{*}+\mathrm{O}_{2}=\mathrm{OH}+\mathrm{O}_{2}$ & $2.10 \cdot 10^{12}$ & 0.5 & -2.02 & [43] \\
\hline $\mathrm{R} 5$ & $\mathrm{OH}^{*}+\mathrm{H}_{2} \mathrm{O}=\mathrm{OH}+\mathrm{H}_{2} \mathrm{O}$ & $5.93 \cdot 10^{12}$ & 0.5 & -3.61 & [43] \\
\hline $\mathrm{R} 6$ & $\mathrm{OH}^{*}+\mathrm{H}_{2}=\mathrm{OH}+\mathrm{H}_{2}$ & $2.95 \cdot 10^{12}$ & 0.5 & -1.86 & {$[43]$} \\
\hline R7 & $\mathrm{OH}^{*}+\mathrm{CO}_{2}=\mathrm{OH}+\mathrm{CO}_{2}$ & $2.76 \cdot 10^{12}$ & 0.5 & -4.06 & {$[43]$} \\
\hline $\mathrm{R} 8$ & $\mathrm{OH}^{*}+\mathrm{CO}=\mathrm{OH}+\mathrm{CO}$ & $3.23 \cdot 10^{12}$ & 0.5 & -3.3 & [43] \\
\hline R9 & $\mathrm{OH}^{*}+\mathrm{CH}_{4}=\mathrm{OH}+\mathrm{CH}_{4}$ & $3.36 \cdot 10^{12}$ & 0.5 & -2.66 & [43] \\
\hline R10 & $\mathrm{OH}^{*}+\mathrm{OH}=\mathrm{OH}+\mathrm{OH}$ & $6.01 \cdot 10^{12}$ & 0.5 & -3.19 & [43] \\
\hline R11 & $\mathrm{OH}^{*}+\mathrm{H}=\mathrm{OH}+\mathrm{H}$ & $1.31 \cdot 10^{13}$ & 0.5 & -0.7 & [43] \\
\hline $\mathrm{R} 12$ & $\mathrm{OH}^{*}+\mathrm{Ar}=\mathrm{OH}+\mathrm{Ar}$ & $1.69 \cdot 10^{12}$ & 0.0 & 17.32 & [49] \\
\hline \multicolumn{6}{|c|}{$\mathrm{CH}(\mathrm{A})$ reactions } \\
\hline$\overline{\mathrm{R} 13}$ & $\mathrm{C}_{2} \mathrm{H}+\mathrm{O}_{2}=\mathrm{CH}(\mathrm{A})+\mathrm{CO}_{2}$ & $3.20 \cdot 10^{11}$ & 0.0 & 6.7 & [39] \\
\hline R14 & $\mathrm{C}_{2} \mathrm{H}+\mathrm{O}=\mathrm{CH}(\mathrm{A})+\mathrm{CO}$ & $2.50 \cdot 10^{12}$ & 0.0 & 0.0 & [39] \\
\hline $\mathrm{R} 15$ & $\mathrm{C}_{2}+\mathrm{OH}=\mathrm{CH}(\mathrm{A})+\mathrm{CO}$ & $1.11 \cdot 10^{13}$ & 0.0 & 0.0 & {$[38]$} \\
\hline R16 & $\mathrm{C}+\mathrm{H}+\mathrm{M}=\mathrm{CH}(\mathrm{A})+\mathrm{M}$ & $3.63 \cdot 10^{13}$ & 0.0 & 0.0 & {$[38]$} \\
\hline $\mathrm{R} 17$ & $\mathrm{CH}(\mathrm{A})=\mathrm{CH}$ & $1.86 \cdot 10^{06}$ & 0.0 & 0.0 & [38] \\
\hline R18 & $\mathrm{CH}(\mathrm{A})+\mathrm{O}_{2}=\mathrm{CH}+\mathrm{O}_{2}$ & $2.48 \cdot 10^{06}$ & 2.14 & -7.2 & {$[43]$} \\
\hline R19 & $\mathrm{CH}(\mathrm{A})+\mathrm{CO}_{2}=\mathrm{CH}+\mathrm{CO}_{2}$ & $2.40 \cdot 10^{-01}$ & 4.3 & -7.1 & [43] \\
\hline $\mathrm{R} 20$ & $\mathrm{CH}(\mathrm{A})+\mathrm{CO}=\mathrm{CH}+\mathrm{CO}$ & $2.44 \cdot 10^{12}$ & 0.5 & 0.0 & {$[43]$} \\
\hline $\mathrm{R} 21$ & $\mathrm{CH}(\mathrm{A})+\mathrm{CH}_{4}=\mathrm{CH}+\mathrm{CH}_{4}$ & $1.73 \cdot 10^{13}$ & 0.0 & 0.7 & {$[43]$} \\
\hline $\mathrm{R} 22$ & $\mathrm{CH}(\mathrm{A})+\mathrm{H}_{2} \mathrm{O}=\mathrm{CH}+\mathrm{H}_{2} \mathrm{O}$ & $5.30 \cdot 10^{13}$ & 0.0 & 0.0 & {$[43]$} \\
\hline $\mathrm{R} 23$ & $\mathrm{CH}(\mathrm{A})+\mathrm{H}=\mathrm{CH}+\mathrm{H}$ & $2.01 \cdot 10^{14}$ & 0.0 & 5.7 & {$[43]$} \\
\hline $\mathrm{R} 24$ & $\mathrm{CH}(\mathrm{A})+\mathrm{OH}=\mathrm{CH}+\mathrm{OH}$ & $7.13 \cdot 10^{13}$ & 0.0 & 5.7 & {$[43]$} \\
\hline $\mathrm{R} 25$ & $\mathrm{CH}(\mathrm{A})+\mathrm{H}_{2}=\mathrm{CH}+\mathrm{H}_{2}$ & $1.47 \cdot 10^{14}$ & 0.5 & 5.7 & [43] \\
\hline $\mathrm{R} 26$ & $\mathrm{CH}(\mathrm{A})+\mathrm{Ar}=\mathrm{CH}+\mathrm{Ar}$ & $3.13 \cdot 10^{11}$ & 0.0 & 0.0 & {$[7]$} \\
\hline \multicolumn{6}{|c|}{$\mathrm{CH}(\mathrm{B})$ reactions } \\
\hline$\overline{\mathrm{R} 27}$ & $\mathrm{C}_{2} \mathrm{H}+\mathrm{O}_{2}=\mathrm{CH}(\mathrm{B})+\mathrm{CO}_{2}$ & $4.27 \cdot 10^{10}$ & 0.0 & 6.7 & $(\mathrm{R} 13)^{a}$ \\
\hline $\mathrm{R} 28$ & $\mathrm{C}_{2} \mathrm{H}+\mathrm{O}=\mathrm{CH}(\mathrm{B})+\mathrm{CO}$ & $3.33 \cdot 10^{11}$ & 0.0 & 0.0 & $(\mathrm{R} 14)^{a}$ \\
\hline R29 & $\mathrm{C}_{2}+\mathrm{OH}=\mathrm{CH}(\mathrm{B})+\mathrm{CO}$ & $1.48 \cdot 10^{12}$ & 0.0 & 0.0 & $(\mathrm{R} 15)^{a}$ \\
\hline R30 & $\mathrm{C}+\mathrm{H}+\mathrm{M}=\mathrm{CH}(\mathrm{B})+\mathrm{M}$ & $4.84 \cdot 10^{12}$ & 0.0 & 0.0 & $(\mathrm{R} 16)^{a}$ \\
\hline R31 & $\mathrm{CH}(\mathrm{B})=\mathrm{CH}$ & $2.50 \cdot 10^{06}$ & 0.0 & 0.0 & {$[8]$} \\
\hline R32 & $\mathrm{CH}(\mathrm{B})+\mathrm{O}_{2}=\mathrm{CH}+\mathrm{O}_{2}$ & $3.90 \cdot 10^{13}$ & 0.0 & 0.0 & {$[8]^{b}$} \\
\hline R33 & $\mathrm{CH}(\mathrm{B})+\mathrm{CO}_{2}=\mathrm{CH}+\mathrm{CO}_{2}$ & $4.00 \cdot 10^{13}$ & 0.0 & 0.0 & {$[8]^{b}$} \\
\hline R34 & $\mathrm{CH}(\mathrm{B})+\mathrm{CO}=\mathrm{CH}+\mathrm{CO}$ & $2.44 \cdot 10^{12}$ & 0.5 & 0.0 & $(\mathrm{R} 20)$ \\
\hline R35 & $\mathrm{CH}(\mathrm{B})+\mathrm{CH}_{4}=\mathrm{CH}+\mathrm{CH}_{4}$ & $1.65 \cdot 10^{13}$ & 0.0 & 0.0 & {$[8]^{b}$} \\
\hline R36 & $\mathrm{CH}(\mathrm{B})+\mathrm{H}_{2} \mathrm{O}=\mathrm{CH}+\mathrm{H}_{2} \mathrm{O}$ & $5.30 \cdot 10^{13}$ & 0.0 & 0.0 & (R22) \\
\hline R37 & $\mathrm{CH}(\mathrm{B})+\mathrm{H}=\mathrm{CH}+\mathrm{H}$ & $2.01 \cdot 10^{14}$ & 0.0 & 5.7 & (R23) \\
\hline R38 & $\mathrm{CH}(\mathrm{B})+\mathrm{OH}=\mathrm{CH}+\mathrm{OH}$ & $7.13 \cdot 10^{13}$ & 0.0 & 5.7 & (R24) \\
\hline R39 & $\mathrm{CH}(\mathrm{B})+\mathrm{H}_{2}=\mathrm{CH}+\mathrm{H}_{2}$ & $1.47 \cdot 10^{14}$ & 0.5 & 5.7 & $(\mathrm{R} 25)$ \\
\hline
\end{tabular}




\begin{tabular}{|c|c|c|c|c|c|}
\hline $\mathrm{R} 40$ & $\mathrm{CH}(\mathrm{B})+\mathrm{Ar}=\mathrm{CH}+\mathrm{Ar}$ & $6.60 \cdot 10^{11}$ & 0.0 & 0.0 & {$[7]$} \\
\hline $\mathrm{R} 41$ & $\mathrm{CH}(\mathrm{B})=\mathrm{CH}(\mathrm{A})$ & $5.00 \cdot 10^{07}$ & 0.0 & 0.0 & estimate \\
\hline \multicolumn{6}{|c|}{$\mathrm{C}_{2} *$ reactions } \\
\hline $\mathrm{R} 42$ & $\overline{{ }^{1} \mathrm{CH}_{2}}+\mathrm{C}=\mathrm{C}_{2}{ }^{*}+\mathrm{H}_{2}$ & $2.40 \cdot 10^{12}$ & 0.0 & 0.0 & {$[40]$} \\
\hline $\mathrm{R} 43$ & $\mathrm{C}_{3}+\mathrm{O}=\mathrm{C}_{2} *+\mathrm{CO}$ & $4.22 \cdot 10^{12}$ & 0.0 & 0.0 & {$[40]$} \\
\hline R44 & $\mathrm{C}_{2} *=\mathrm{C}_{2}$ & $1.00 \cdot 10^{07}$ & 0.0 & 0.0 & {$[40]$} \\
\hline $\mathrm{R} 45$ & $\begin{array}{l}\mathrm{C}_{2} *+\mathrm{M}=\mathrm{C}_{2}+\mathrm{M} \\
\mathrm{M}=\mathrm{O}_{2}, \mathrm{CO}_{2}, \mathrm{H}_{2} \mathrm{O}, \mathrm{CO}, \mathrm{CH}_{4}, \mathrm{H}_{2}, \mathrm{Ar}\end{array}$ & $4.80 \cdot 10^{13}$ & 0.0 & 0.0 & {$[40]$} \\
\hline \multicolumn{6}{|c|}{ C reactions } \\
\hline $\mathrm{R} 46$ & $\mathrm{C}+\mathrm{H}_{2} \mathrm{O}=\mathrm{CHO}+\mathrm{H}$ & $3.00 \cdot 10^{12}$ & 0.0 & 0.0 & [36] \\
\hline $\mathrm{R} 47$ & $\mathrm{C}+\mathrm{OH}=\mathrm{H}+\mathrm{CO}$ & $5.00 \cdot 10^{13}$ & 0.0 & 0.0 & {$[37]$} \\
\hline $\mathrm{R} 48$ & $\mathrm{C}+\mathrm{OH}=\mathrm{CH}+\mathrm{O}$ & $2.40 \cdot 10^{14}$ & 0.0 & 91.0 & {$[36]$} \\
\hline R49 & $\mathrm{C}+\mathrm{CH}=\mathrm{C}_{2}+\mathrm{H}$ & $1.00 \cdot 10^{13}$ & 0.0 & 0.0 & {$[40]$} \\
\hline R50 & $\mathrm{C}+{ }^{1} \mathrm{CH}_{2}=\mathrm{C}_{2}+\mathrm{H}_{2}$ & $3.00 \cdot 10^{12}$ & 0.0 & 0.0 & {$[46]$} \\
\hline R51 & $\mathrm{C}+{ }^{3} \mathrm{CH}_{2}=\mathrm{C}_{2}+\mathrm{H}_{2}$ & $3.00 \cdot 10^{12}$ & 0.0 & 0.0 & {$[46]$} \\
\hline \multicolumn{6}{|c|}{$\mathrm{C}_{2}$ reactions } \\
\hline$\overline{\mathrm{R}} 52$ & $\mathrm{C}_{2} \mathrm{H}+\mathrm{O}=\mathrm{C}_{2}+\mathrm{OH}$ & $1.20 \cdot 10^{13}$ & 0.0 & 0.0 & {$[36]$} \\
\hline R53 & $\mathrm{C}_{2} \mathrm{H}+\mathrm{H}=\mathrm{C}_{2}+\mathrm{H}_{2}$ & $6.20 \cdot 10^{13}$ & 0.0 & 73.0 & {$[36]$} \\
\hline R54 & $\mathrm{C}_{2}+\mathrm{OH}=\mathrm{C}_{2} \mathrm{O}+\mathrm{H}$ & $5.00 \cdot 10^{13}$ & 0.0 & 0.0 & {$[46]$} \\
\hline R55 & $\mathrm{C}_{2}+\mathrm{O}_{2}=\mathrm{CO}+\mathrm{CO}$ & $9.00 \cdot 10^{12}$ & 0.0 & 4.1 & [1] \\
\hline R56 & $\mathrm{C}_{2}+\mathrm{O}=\mathrm{CO}+\mathrm{C}$ & $1.00 \cdot 10^{14}$ & 0.0 & 0.0 & {$[46]$} \\
\hline R57 & $\mathrm{C}_{2}+\mathrm{OH}=\mathrm{CH}+\mathrm{CO}$ & $5.00 \cdot 10^{13}$ & 0.0 & 0.0 & {$[46]$} \\
\hline $\mathrm{R} 58$ & $\mathrm{C}_{2}+\mathrm{CH}_{4}=\mathrm{C}_{2} \mathrm{H}+\mathrm{CH}_{3}$ & $3.00 \cdot 10^{13}$ & 0.0 & 2.47 & {$[46]$} \\
\hline R59 & $\mathrm{C}_{2}+\mathrm{C}_{2} \mathrm{H}_{2}=\mathrm{C}_{2} \mathrm{H}+\mathrm{C}_{2} \mathrm{H}$ & $1.00 \cdot 10^{14}$ & 0.0 & 0.0 & {$[46]$} \\
\hline R60 & $\mathrm{C}_{2}+\mathrm{C}_{2} \mathrm{H}_{4}=\mathrm{C}_{2} \mathrm{H}+\mathrm{C}_{2} \mathrm{H}_{3}$ & $1.00 \cdot 10^{14}$ & 0.0 & 0.0 & {$[46]$} \\
\hline R61 & $\mathrm{C}_{2}+\mathrm{C}_{2} \mathrm{H}_{6}=\mathrm{C}_{2} \mathrm{H}+\mathrm{C}_{2} \mathrm{H}_{5}$ & $5.00 \cdot 10^{13}$ & 0.0 & 0.0 & {$[46]$} \\
\hline \multicolumn{6}{|c|}{$\mathrm{C}_{2} \mathrm{O}$ reactions } \\
\hline$\overline{\mathrm{R} 62}$ & $\mathrm{C}_{2}+\mathrm{O}_{2}=\mathrm{C}_{2} \mathrm{O}+\mathrm{O}$ & $2.00 \cdot 10^{14}$ & 0.0 & 33.8 & {$[1]$} \\
\hline R63 & $\mathrm{CH}+\mathrm{CO}=\mathrm{C}_{2} \mathrm{O}+\mathrm{H}$ & $1.90 \cdot 10^{11}$ & 0.0 & 0.0 & {$[36]$} \\
\hline R64 & $\mathrm{C}_{2} \mathrm{O}+\mathrm{O}=\mathrm{CO}+\mathrm{CO}$ & $4.80 \cdot 10^{13}$ & 0.0 & 0.0 & {$[29]$} \\
\hline R65 & $\mathrm{C}_{2} \mathrm{O}+\mathrm{OH}=\mathrm{CH}+\mathrm{CO}_{2}$ & $2.00 \cdot 10^{13}$ & 0.0 & 0.0 & {$[46]$} \\
\hline \multicolumn{6}{|c|}{$\mathrm{C}_{3}$ reactions } \\
\hline$\overline{\mathrm{R} 66}$ & $\overline{\mathrm{C}+} \mathrm{C}_{2} \mathrm{H}=\mathrm{C}_{3}+\mathrm{H}$ & $2.00 \cdot 10^{16}$ & -1.0 & 0.0 & {$[40]$} \\
\hline $\mathrm{R} 67$ & $\mathrm{C}_{2}+\mathrm{CH}=\mathrm{C}_{3}+\mathrm{H}$ & $5.00 \cdot 10^{13}$ & 0.0 & 0.0 & {$[40]$} \\
\hline R68 & $\mathrm{C}_{3}+\mathrm{OH}=\mathrm{CO}+\mathrm{C}_{2} \mathrm{H}$ & $8.00 \cdot 10^{13}$ & 0.0 & 0.0 & {$[40]^{c}$} \\
\hline R69 & $\mathrm{C}_{3}+\mathrm{O}_{2}=\mathrm{CO}_{2}+\mathrm{C}_{2}$ & $9.00 \cdot 10^{11}$ & 0.0 & 91.5 & {$[21]^{c}$} \\
\hline R70 & $\mathrm{C}_{3}+\mathrm{O}=\mathrm{CO}+\mathrm{C}_{2}$ & $5.00 \cdot 10^{13}$ & 0.0 & 0.0 & {$[21]$} \\
\hline \multicolumn{6}{|c|}{$\mathrm{C}_{3} \mathrm{H}_{2}$ reactions } \\
\hline$\overline{\mathrm{R} 71}$ & $\mathrm{CH}+\mathrm{C}_{2} \mathrm{H}_{2}=\mathrm{C}_{3} \mathrm{H}_{2}+\mathrm{H}$ & $9.40 \cdot 10^{13}$ & 0.0 & -2.09 & {$[40]$} \\
\hline R72 & $\mathrm{C}_{3} \mathrm{H}+\mathrm{H}_{2}=\mathrm{C}_{3} \mathrm{H}_{2}+\mathrm{H}$ & $4.00 \cdot 10^{05}$ & 2.4 & 4.2 & {$[40]$} \\
\hline R73 & $\mathrm{C}_{3} \mathrm{H}_{2}+\mathrm{O}=\mathrm{CHO}+\mathrm{C}_{2} \mathrm{H}$ & $4.00 \cdot 10^{13}$ & 0.0 & 0.0 & {$[40]$} \\
\hline R74 & $\mathrm{C}_{3} \mathrm{H}_{2}+\mathrm{OH}=\mathrm{CHO}+\mathrm{C}_{2} \mathrm{H}_{2}$ & $1.00 \cdot 10^{13}$ & 0.0 & 0.0 & {$[40]$} \\
\hline \multicolumn{6}{|c|}{$\mathrm{C}_{3} \mathrm{H}$ reactions } \\
\hline$\overline{\mathrm{R} 75}$ & $\mathrm{C}_{3}+\mathrm{H}_{2}=\mathrm{C}_{3} \mathrm{H}+\mathrm{H}$ & $4.10 \cdot 10^{05}$ & 2.4 & 92.0 & {$[40]$} \\
\hline R76 & $\mathrm{CH}+\mathrm{C}_{2} \mathrm{H}=\mathrm{C}_{3} \mathrm{H}+\mathrm{H}$ & $5.00 \cdot 10^{13}$ & 0.0 & 0.0 & [40] \\
\hline R77 & $\mathrm{C}_{3} \mathrm{H}+\mathrm{O}=\mathrm{CO}+\mathrm{C}_{2} \mathrm{H}$ & $4.00 \cdot 10^{13}$ & 0.0 & 0.0 & {$[40]$} \\
\hline
\end{tabular}




$\begin{array}{llllll}\mathrm{R} 78 & \mathrm{C}_{3} \mathrm{H}+\mathrm{OH}=\mathrm{CO}+\mathrm{C}_{2} \mathrm{H}_{2} & 2.00 \cdot 10^{13} & 0.0 & 0.0 & {[40]} \\ \mathrm{R} 79 & \mathrm{C}_{3} \mathrm{H}+\mathrm{O}_{2}=\mathrm{CO}+\mathrm{HCCO} & 3.00 \cdot 10^{13} & 0.0 & 0.0 & {[40]}\end{array}$

$a$ : Pre-exponential factor $A$ modified in present work, multiplied by factor of 0.13

$b: k_{295 K}$ extrapolated to temperature at peak $\mathrm{CH}(\mathrm{B})$ by using T-dependence from equivalent $\mathrm{CH}(\mathrm{A})$ reaction

$c$ : Rates not original recommendations, modified in present work 